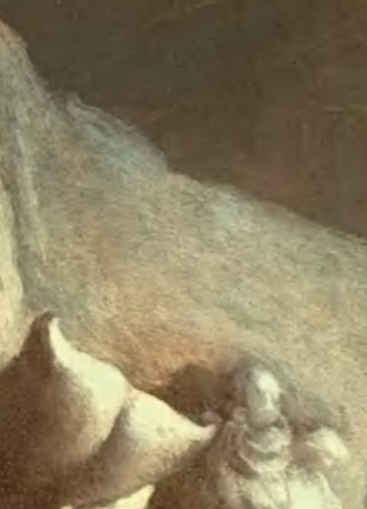




\section{Paludanus, alabaster, and the erotic appeal of art in Antwerp}

Giancarlo Fiorenza

Titian's fascinating portrait of Jacopo Strada $\left(1567^{-15} 68\right)$ has proven to be a touchtone for art historians, offering an absorbing visual document, albeit artfully contrived, for inquiry into the fields of collecting and experiencing sculpture in the Renaissance (fig. 1). How can viewers not be swayed by the image of a polymath collector who, while gazing out beyond his study as if

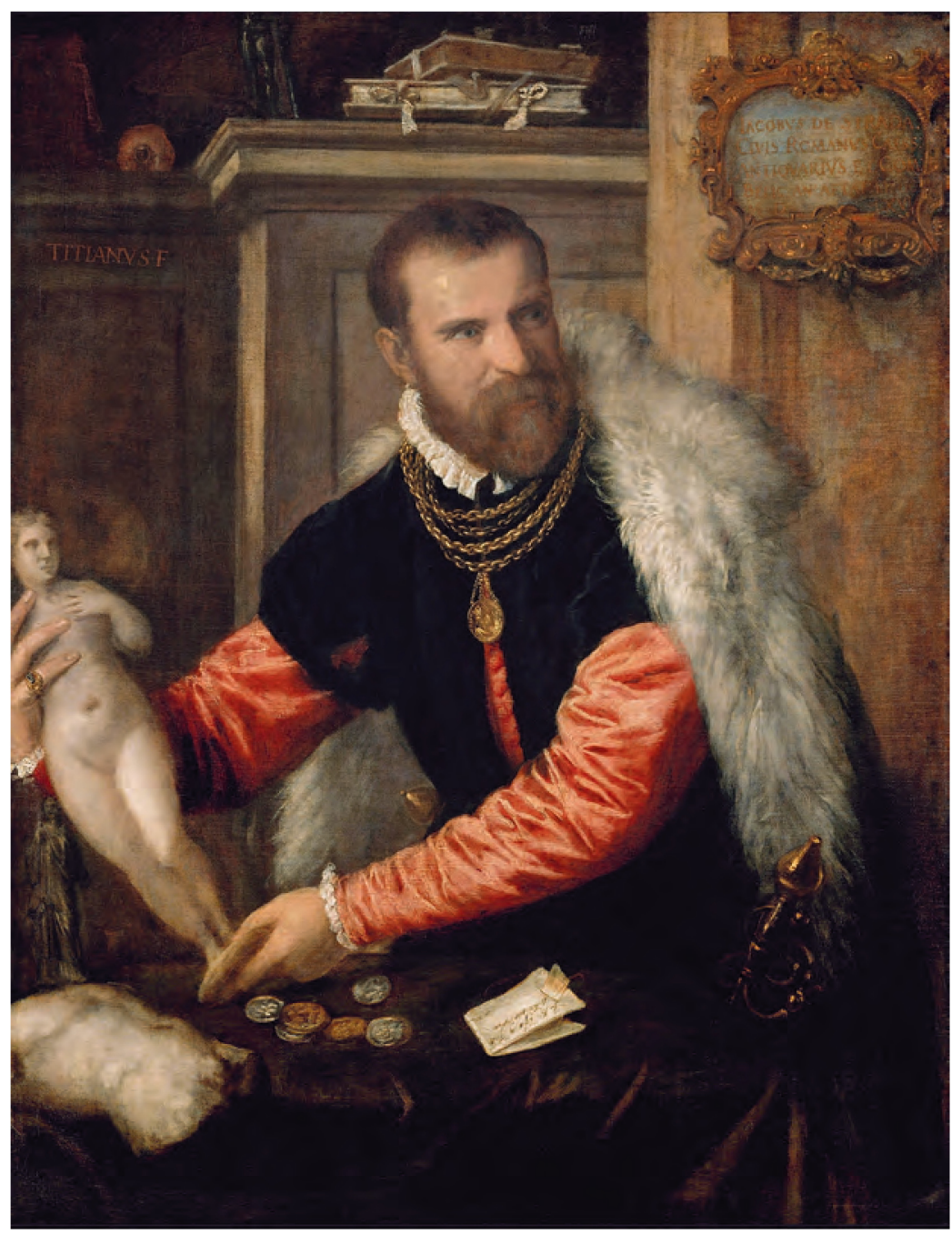

Detail fig. 3

Titian, Portrait of Jacopo Strada, 1567-1568, oil on canvas, Vienna, Kunsthistorisches Museum (photo: courtesy of Wikimedia Commons) 
2

Lorenzo Lotto, Portrait of Andrea Odoni, $\mathbf{1 5 2 7}$, oil on canvas, London, Royal Collection (photo: courtesy of Wikimedia Commons) distracted by an intruder, cradles a marble statuette of a nude goddess and is surrounded by coins, books, letters, and other sculptural objects? Titian portrays Strada's hand over one of the breasts of the statuette in a gesture that serves to hold, cover, and caress the object simultaneously, mirroring the goddess's own hand over her other breast. Desire and possession fuel one another, as both the represented object and the portrait as a whole warrant a sensual response. ${ }^{2}$ Titian invites a paragone with sculpture, awaking the senses with his imagery and virtuoso colorito brushwork, further amplifying the tactile nature of his art and its vivifying effect. ${ }^{3}$ Images of collectors or artists either handling or surrounded by sculptural objects abound in sixteenth-century Italian painting, with Lorenzo Lotto's Portrait of Andrea Odoni (1527) (fig. 2) and Parmigianino's Portrait of a collector (c. 1523) (fig. 3) standing as two more compelling examples. The vigorous poses and amorous embraces of the represented sculptural figures in these portraits give the impression that collectors valued three-

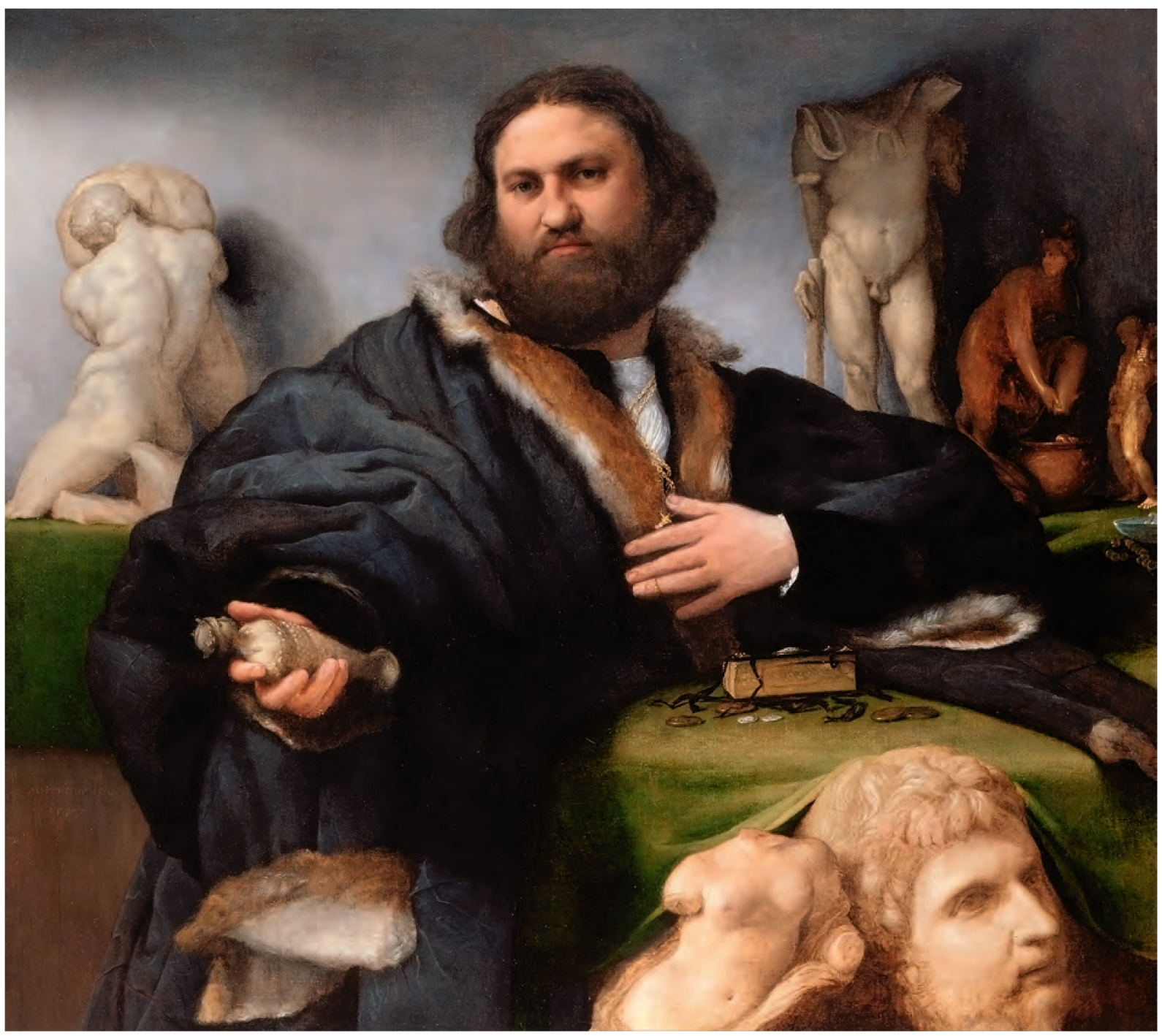




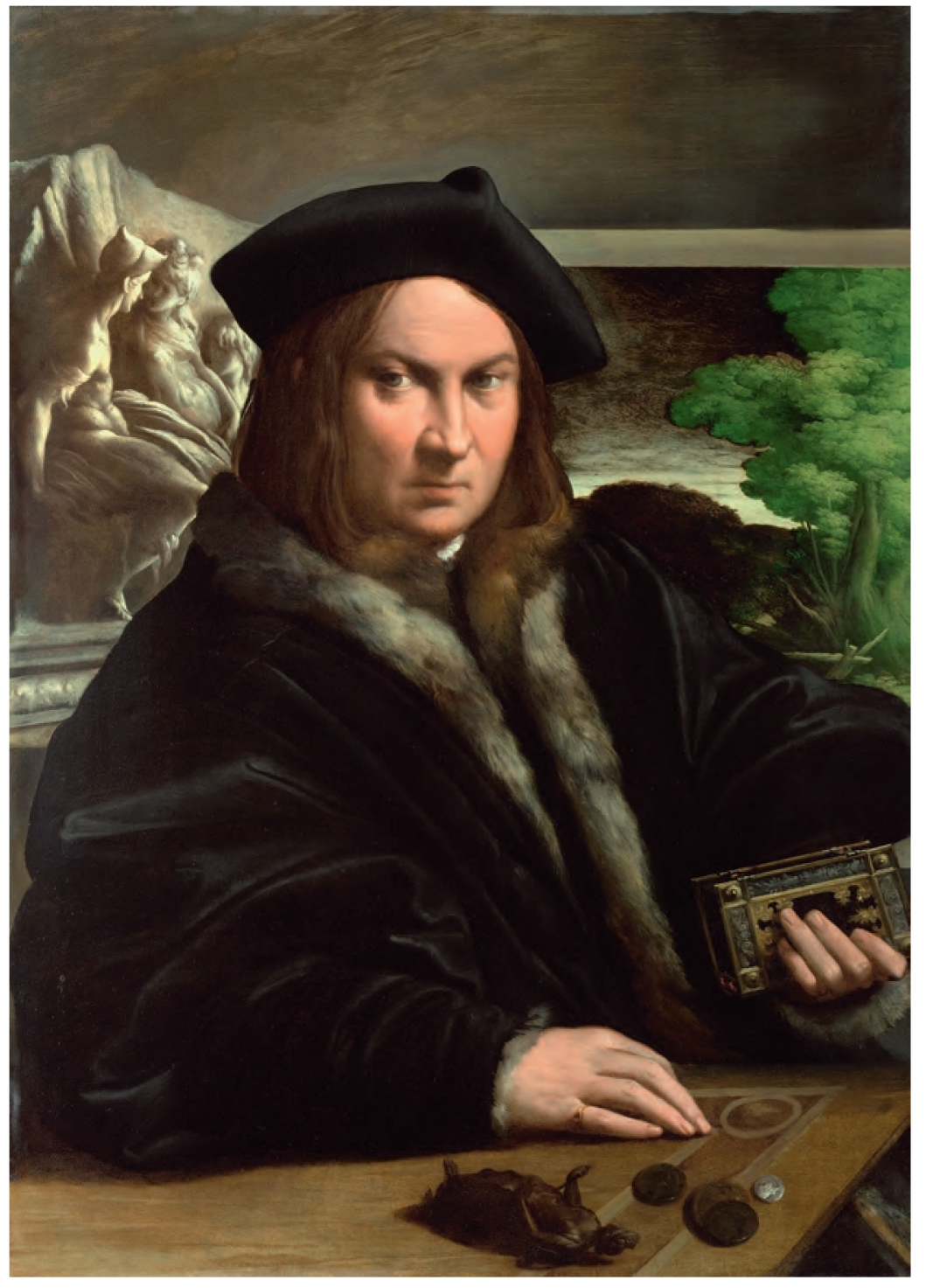

dimensional works of art for their apparent life force. Recent studies have also demonstrated that the images of Natura, Ceres, and Venus are not mere compositional ornaments, but validate inquiry into the realms of nature and love as generative and unruly forces governing the human condition - theories espoused by Lucretius in his widely popular De rerum natura. ${ }^{4}$ It follows that the collectors in these Italian Renaissance portraits exhibit an obsessive and near idolatrous craving for objects that they wish to savor with their audiences.

The opposite is true for Renaissance painting in the Netherlands, where a relative dearth of corresponding imagery survives - if it ever existed designating the sensual and frankly erotic appeal that small-scale sculpture must have afforded collectors. Despite the absence of visual testimony, the issue of how Netherlandish collectors experienced cabinet sculpture is all

\section{3}

Parmigianino, Portrait of a collector, c. 1523, oil on panel, London, National Gallery

(photo: courtesy of Wikimedia Commons) 
the more pressing when considering the art of Willem van den Broecke, alias Paludanus (1530-1580), who specialized in the production of exquisitely carved alabaster sculpture, not unlike the examples - real or imagined one finds in the portraits by Titian, Lotto, and Parmigianino. ${ }^{5}$ So coveted by collectors were his alabasters that in 1587 Gabriel Kaltemarckt commended him as a requisite artist to be included in a royal Kunstkammer. In addition to treating a variety of religious narratives, Paludanus carved statuettes depicting mythological subjects that invoke notions of love, beauty, and sexual desire. The sculptor refashioned figures from ancient myth and poetry - and even existing ancient statues - to invite an experience centered on the fascination of sensuous surfaces and the longing to touch and possess the object.? As Aleksandra Lipińska has established, alabaster had strong associations with the human body, not just the sanctified body, but the physical and poetic ones as well. ${ }^{8}$ The appreciation of the seductive properties of art and its materials as they relate to the female body features in the vernacular lyrics of Het Bosken (The small wood) by Jan van der Noot (c. 1539-after 1595), a collection of poetry that he mainly composed in Antwerp but published only in 1570/1571 while the author was in exile in London, from 1567 , for religious and political reasons. Het Bosken is composed in a meter novel to Netherlandish literature and is indebted to the sonnets of Pierre de Ronsard (1524-1585), who was highly prized for his expressive energies and pictorial diction in describing female beauty and the transformative powers of desire. In one sonnet, Van der Noot lovingly describes the body of his beloved, praising her golden hair, ebony eyebrows, coral mouth, ivory teeth, and 'breasts of alabaster.'. One of the most captivating images of the alabaster body is found in canto 10 of Ludovico Ariosto's Orlando furioso (1532), when the paladin Ruggiero flies on his hippogryph and spots the beautiful Angelica about to be devoured by a sea monster. He is immediately fascinated by her beauty and overcome with emotion. Angelica, nude (ignuda) and chained to a rock, appears as a statue fashioned in alabaster or lambent marble (Creduto avria che fosse statua finta/ o d'alabastro o d'altri marmi illustri). ${ }^{10}$ Fixing his eyes on hers, Ruggiero remembers his own beloved Bradamante, and the sight of Angelica's peril moves him to tears. Angelica's poetic body merges with the idea of a sculptural one, kindling the memory of an absent beloved.

The motif of the alabaster body - the beautiful body with mesmerizing qualities - was a commonplace in Italian, French, and Flemish lyric verse that had important connections with the visual arts. That Paludanus's alabaster sculptures carried a beguiling power able to eclipse their status as commodities is evidenced, in part, by the passionate investment afforded works of art in the vernacular poetry of another contemporary, Lucas de Heere (1534-1584). As we shall see, De Heere frequently recasts the Pygmalion narrative involving enlivening artifice, creating an expressive mode in relation to painting, sculpture, and poetry that coincides with the emergence of an 'affective beholder' in Antwerp." The poetry of De Heere, like that of Van der Noot, largely imitates the lyrics composed by Italian and French poets, such as Petrarch (1304-1374) and Clément Marot (14961544), and writers associated with the Pléiade, especially Ronsard. The reception and circulation of French poetry in the Netherlands was profuse 
and supplied a model of imitation for numerous vernacular works. Jan Cauweel, who published Matthijs de Castelein's De Const van Rhetoriken posthumously in Ghent in 1555, championed the embellishment, printing, and distribution of Netherlandish poetic and rhetorical arts based on the example of the Pléiade poets..$^{12}$ In light of the scarcity of documentation on Paludanus's secular alabasters, the writings of his contemporaries provide the most salient context to interpret his art, suggesting ways in which audiences could interact with his sculptures and channel amorous yearnings characteristic of Renaissance vernacular lyric. The appeal to poetics in the present study underscores the confluence of eloquence between the verbal and visual arts, likening the vivid, ornamental, and seductive nature of Flemish and French vernacular verse to Netherlandish art in their respective ability to enthrall audiences and instill a longing to possess beauty.13

Paludanus, who came from a family of artists working in both sculpture and painting, originated from Mechelen but was primarily active in Antwerp, the two main centers for the production of alabaster sculpture in the sixteenth century. ${ }^{14}$ In 1557 he was admitted as a free master in the Antwerp guild of St. Luke, under the name 'Gilliaeme van den Broecke beeltsnider, alias Paludanus'. As Titia de Haseth Möller and Frits Scholten observe, his use of the Latinized Paludanus in the register and as a signature in some of his subsequent works distinguishes him from other artists working in alabaster around the same time and is a clear indication of his 'humanist ambitions.'15 Indeed, he was praised by such literary contemporaries as Lodovico Guicciardini, Giorgio Vasari, and Pieter van Opmeer. While Paludanus produced small-scale alabasters mainly for local Antwerp clients, he also worked in marble and made both small- and largescale works for export to such cities as Augsburg, Schwerin, and Lübeck. Notably, the artist enjoyed the patronage of illustrious international clients as well, including Fernando Álvarez de Toledo, the third Duke of Alba (1507-1582), who served as governing Captain-General of the Spanish Netherlands and was stationed in the Low Countries from 1567 to 1573. Alba commissioned various works from Paludanus, some destined for export to Spain. The house Paludanus built in 1567 on the Korte Vaartstraat in Antwerp was named De Liefde, and he decorated it with imagery related to the theme of love, including a relief depicting Adam and Eve joining hands in the Garden of Eden. ${ }^{16}$ It has been suggested that the name implies an association with the Huis der Liefde (Family of Love), a mystic religious sect preaching religious tolerance. ${ }^{17}$ Given that the civic motto of Antwerp was Fides et amor, however, the appellation of Paludanus's home more readily speaks to the sculptor's cultivation of love and friendship within the artistic community of Antwerp and beyond. ${ }^{18}$ For example, Anthonius Mor (c. 1517-1577), court painter for King Philip II of Spain, named Paludanus one of the executors of his will, and in such a role the sculptor received from the painter 'certain books in which he had made notes'.19 Mor's bibliographic bequest to Paludanus can be seen as a token of a bond of affection and erudition between the two artists; it also carried the obligation for Paludanus to be a guardian for Mor's daughter after the painter's death. ${ }^{20}$ Because Paludanus developed international relations 
with friends and patrons alike, it follows that his sculpture had a broad appeal in terms of how he imitated and updated myth and antiquity.

Paludanus's Aphrodite drying herself (c. 1560) (figs. 4, 5), a recently attributed work, is a supreme example of the artist's revision of antiquity into a modern, collectible object. ${ }^{21}$ Carved from alabaster, it measures 34 centimeters high and is based on an antique statue that was in Rome, of Aphrodite binding her sandal..$^{22}$ Although his trip is undocumented, Paludanus likely visited Italy together with his brother, the painter Hendrick van den Broecke (c. 1530-1597), sometime before 1557. Whether or not Paludanus had the opportunity to study his antique model directly, his alabaster is far from a straightforward replica, even beyond its dramatically reduced scale and precious material. The artist altered or invented the

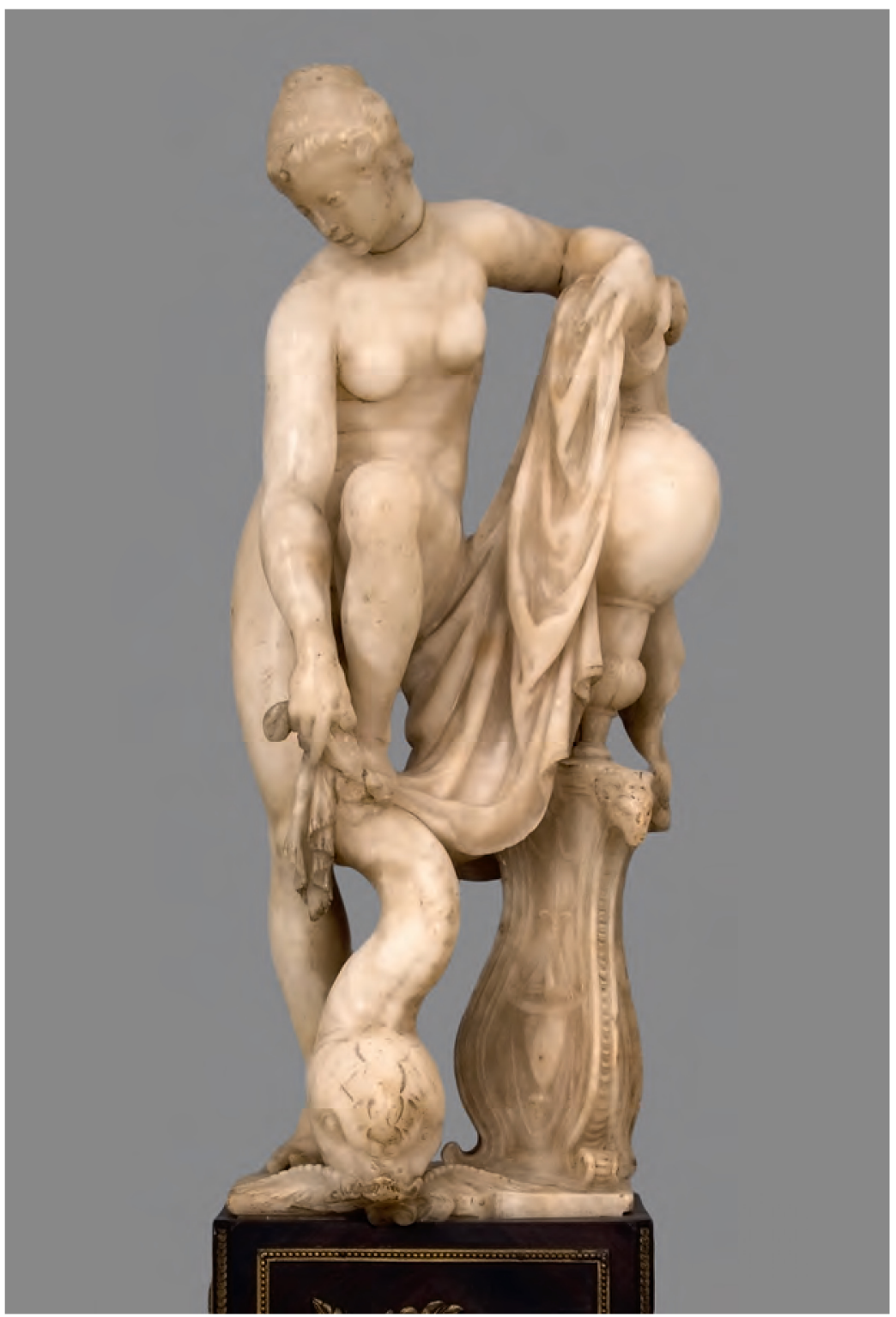

Paludanus (Willem van den Broecke),

Aphrodite drying herself, c. 1560 , alabaster, h. $34 \mathrm{~cm}$, Milan, Museo Poldi Pezzoli (photo: Andrea di Lorenzo, Milan) 
position of the arms to suit his subject's action. He also incorporated a stand, vase, and dolphin to accentuate the twisting figure of Aphrodite, aligning her body to the elegant forms found in nature and ornamental objects. ${ }^{23}$ Designed to be admired in the round, and in a material that is more delicate and supple to the touch than marble, the Aphrodite was meant to be handled as part of the overall enjoyment of the work. Paludanus exploits the aesthetic value of the alabaster, allowing its milky color and translucent qualities to simulate the supple body and skin of the goddess. To a certain extent, Paludanus's invention relates to the efforts of Pier Jacopo Alari Bonacolsi (c. 1460-1528), the Italian sculptor known as Antico, celebrated for his numerous small-scale bronzes, frequently gilded, based on ancient statues. In a letter to Isabella d'Este from April 1519, Antico judges his modern

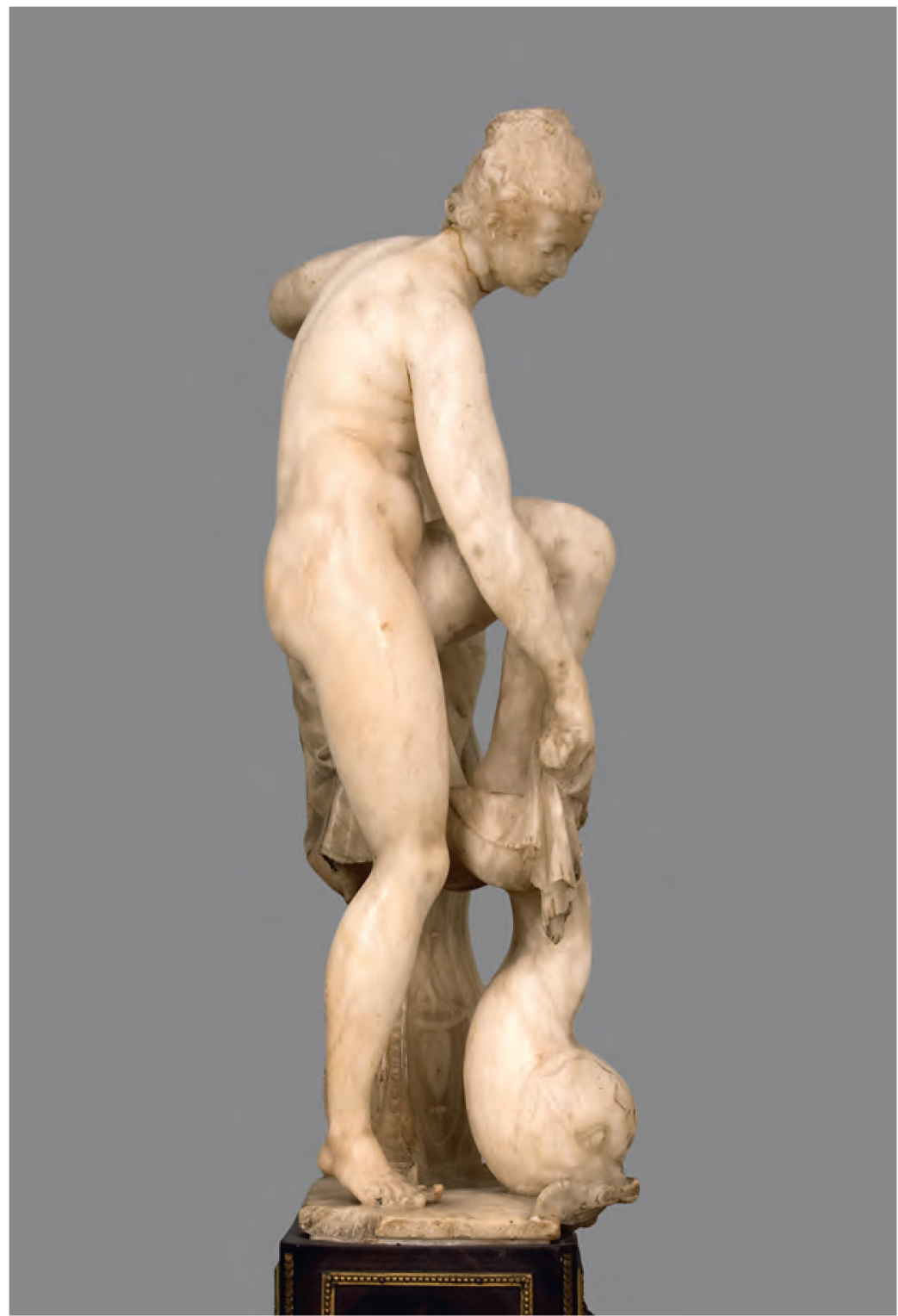

Paludanus (Willem van den Broecke), Aphrodite drying herself (side view), c. 156o, alabaster, h. $34 \mathrm{~cm}$, Milan, Museo Poldi Pezzoli (photo: Andrea di Lorenzo, Milan) 
creations to be more beautiful than ancient works. ${ }^{24}$ Whether alabaster or bronze, such statuettes supplant the achievements of ancient sculpture and cleverly displace the hierarchy between origin and imitation.

Images of Venus in the Renaissance were seen as embodiments of love. In defining the nature of the goddess in his Genealogie deorum gentilium, a best seller in the sixteenth century, Giovanni Boccaccio (1313-1375) states how Venus signifies 'an adornment for every thing' as well as 'fornication of every kind and wantonness and a multitude of coition, the guardianship of statues and pictures (magisteria circa statuas et picturas), the composition of wreaths and wearing of garments, weavings with gold and silver'.25 Venus's mastery over the arts should come as no surprise, especially in the field of sculpture, given that she granted life to Pygmalion's exquisitely wrought ivory statue. According to the myth made popular by Ovid's Metamorphoses (10.243-297) and Boccaccio's Genealogie deorum gentilium (2.49), Pygmalion fashioned the statue after his own unrequited desire, engendering a simulacrum so beautiful that he fell in love with his own artifice: their union even produced a child. In addition, Pliny the Elder helped codify the legend that the sculptor Praxiteles so infused the nature of love into his marble sculpture of the Cnidian Venus that the statue's superior beauty compelled a young man to copulate with it and leave a stain. ${ }^{26}$ Such ancient concepts reinforced Renaissance theories that sexual desire drove artistic creation and reception. It follows that Paludanus's alabaster placed the collector in the position of lover, providing an object that supplants nature and fulfills one's sensual longings.

Stylistic comparisons have been observed between the sculpture of Paludanus and that of his more famous contemporary Giambologna (15291608), who often overshadows the former's achievements. ${ }^{27}$ Despite the difference in mediums, it might be more instructive to see Paludanus's efforts in light of Jan Massys's Venus Cytherea, a spectacular painting dated 1561 (fig. 6) ${ }^{28}$ Massys (c. 1509-1575), who worked in Antwerp and most likely traveled to France, assimilated and transformed the latest artistic developments (painting and sculpture) at Fontainebleau into a style all his own. The French court, so fascinated by the ancient world and keen to cultivate an international community of artists, became a model for various courts in northern Europe and the dissemination of new aesthetics. ${ }^{29}$ The goddess's features flirt with the boundaries between nature and artifice, body and ornamental object, as Massys juxtaposes her alabaster-like flesh to the stone vase and fountain statue on the terrace. Writing in 1565 , Domenicus Lampsonius (1532-1599) admonished painters who imitated ancient sculpture so slavishly that they made their figures look like statues of wood or stone. Instead, he commended Titian's ability to render flesh and blood through his variety of colors and impasto application of pigment. ${ }^{30}$ The physicality and materiality of works of art, as Koenraad Jonckheere has discussed, were at the forefront of the image debates in the Netherlands, and Lampsonius, although writing as a humanist, employs the same terminology as the theologians in advocating for a natural pictorial manner. ${ }^{31}$ It may be that Lampsonius had in mind the technique of Massys, who steadfastly emphasizes the lapidary qualities of Venus, as if to render her an idol come to life. 


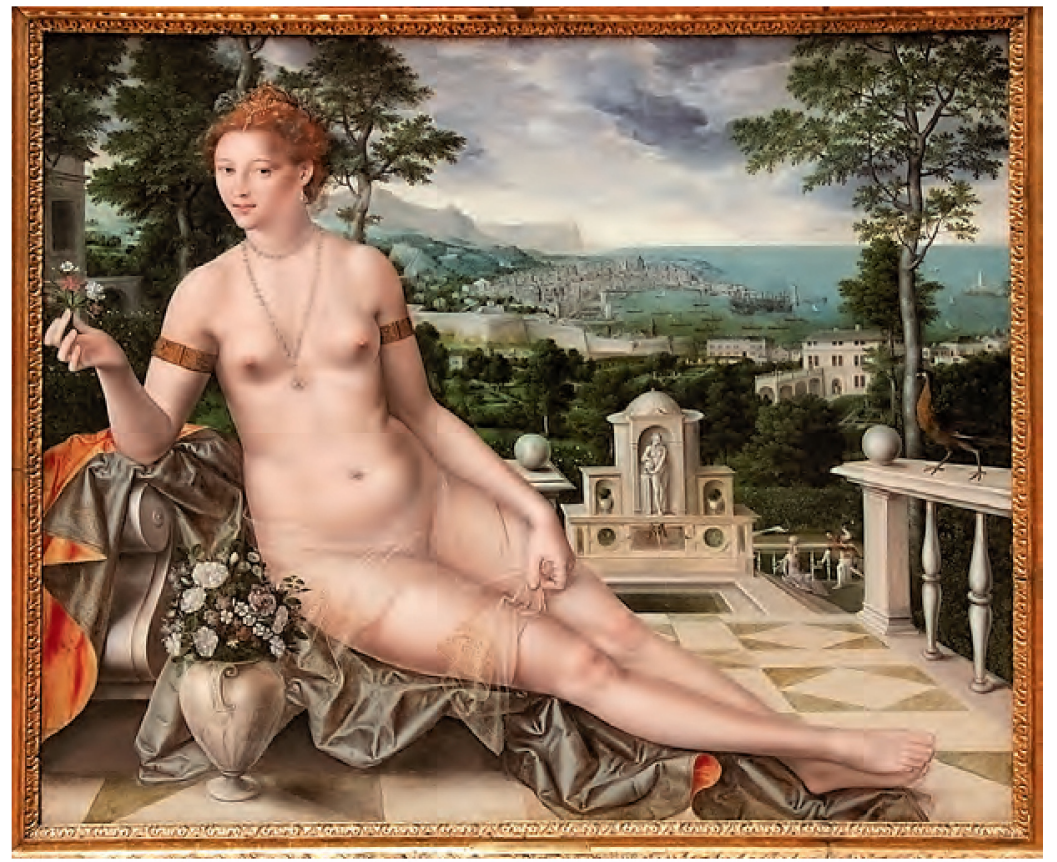

Massys portrays Venus as a poetic ideal of female loveliness, appealing to the convention of the Petrarchan lyric as it was developed in French and Netherlandish verse with her alabaster flesh, golden hair, rosy tints to her facial complexion, and idealized bodily proportions. ${ }^{32}$ Using gemlike metaphors to describe the beloved, often making comparisons to the visual arts, Renaissance lyric poets reify their verbal artifice as they construct an imaginative idea of love. Ronsard's collection Les amours de Cassandre (1552), for example, frequently employs alabaster as a metaphor for beauty when describing women's features. ${ }^{33}$ In his later works Ronsard invokes the paragone with sculpture by comparing the description of his object of desire with the alluring products of Praxiteles and Phidias. ${ }^{34}$ For his part, Massys, by imagining his portrayal of Venus in accordance with the conventions of vernacular lyric, casts the goddess in the role of the lyric beloved whereby he appeals to an affective beholder. The diminutive continuous narrative of courtship that initiates in the background and culminates near the foreground terrace connects viewers with their own memory or expectations of amorous engagement. Simultaneously, the figure of Venus, who stares directly out at the viewer and offers flowers, binds the heart and imagination..$^{35}$

Paludanus's alabaster matches the poetic and idealized features of Massys's Venus in both face and body, and he can be seen to transform the ancient pedigree of the statuette into a lyric object of desire. Furthermore, he allows the handling of his Venus to recreate the Praxitelean narrative of a physical engagement with the goddess, not unlike Strada's caress of the nude statuette in Titian's portrait. Such an imitation and a refashioning of antiquity exploit the tactile nature of alabaster, which warms to the touch, and would have appealed to a Renaissance viewer's haptic as well as lyric

\section{6}

Jan Massys, Venus Cytherea, 1561, oil on panel, Stockholm, Nationalmuseum (photo: courtesy of E. Matt Kavaler) 


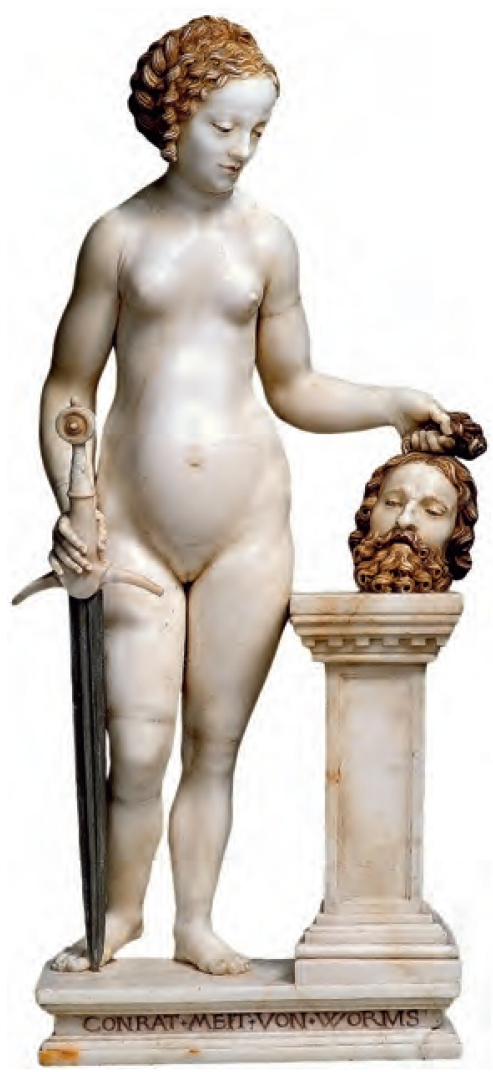

7

Conrat Meit, Judith, c. 1525-1528, alabaster,

Munich, Bayerisches Nationalmuseum (photo: courtesy of Wikimedia Commons) sensibilities. ${ }^{36}$ Recent studies have shown how works of art broadened the horizon of one's affections within Catholic and Reformist communities of the sixteenth century ${ }^{37}$ Even alabaster works showing religious subjects, such as Conrat Meit's Judith (c. 1525-1528) (fig. 7),$^{38}$ or Lot and his daughters (1554) (fig. 8), ${ }^{39}$ produced in the Southern Netherlands, speak to the transgressive power of eros, presenting male protagonists who in their inebriated states succumb to sexual obsession. While such images can be seen to exploit the eroticism of the female nude, they are more a matter of recasting the lustful delirium of the protagonists for viewers to meditate on and experience by means of vivid, physical, and explicit imagery. Art intoxicates the senses and makes one vulnerable.

The sensual and highly poetic nature of Paludanus's art comes to the fore in his Aphrodite and Eros (figs. 9, 10), signed and dated 1559, which

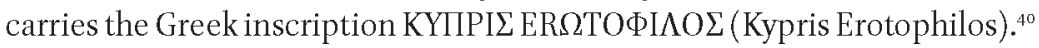
Measuring 25 centimeters high, it is carved to be viewed in the round. Paludanus signed the alabaster with his Latinized name - Guilielmus Paludanus - on the back, where Eros scampers up a tree stump in order to embrace and kiss Aphrodite, albeit somewhat awkwardly and humorously

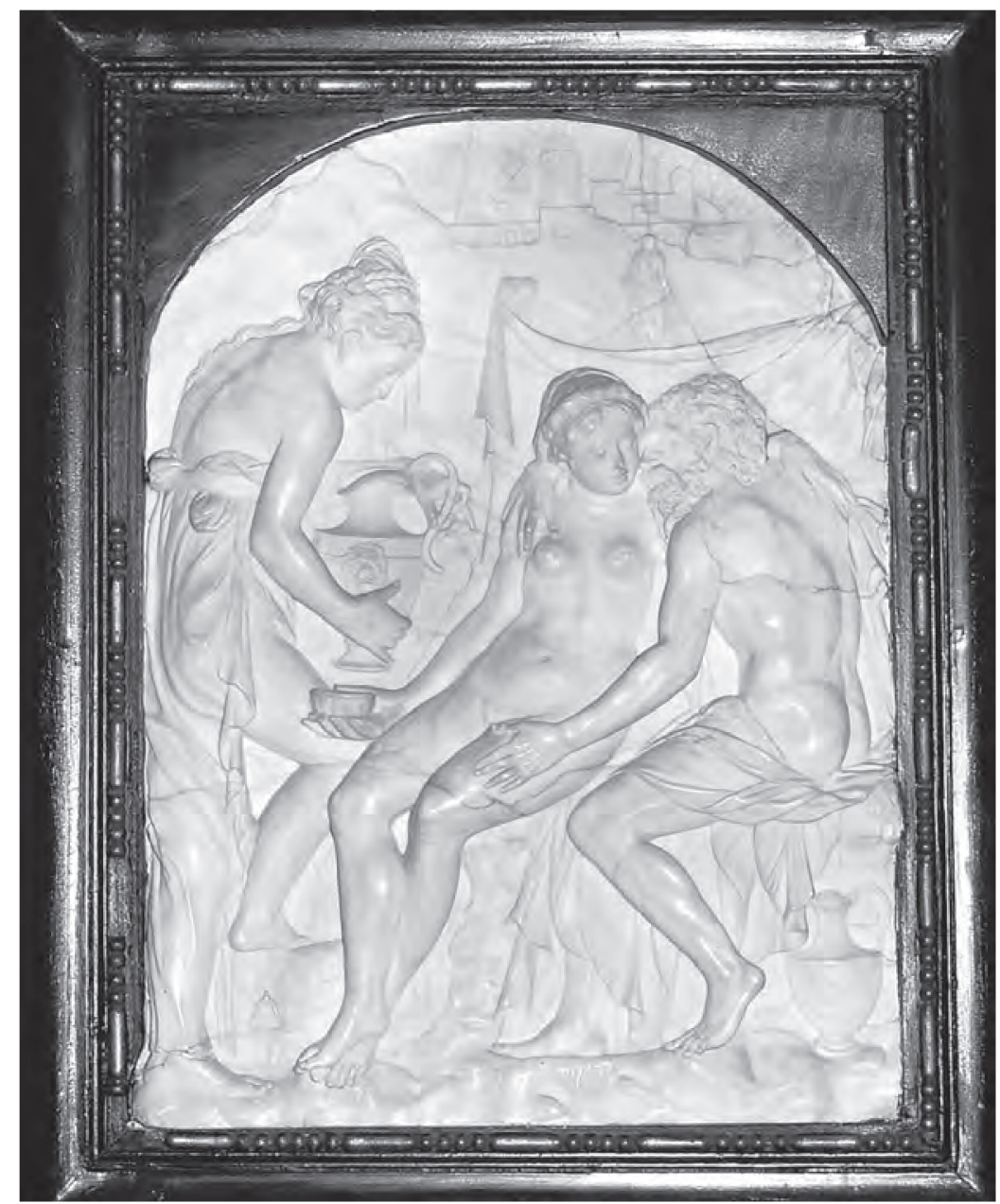


exposing his backside to the viewer. Aphrodite is more elegantly composed, seated in profile yet turning ever so slightly to greet her son. Her body rests over a cloth that she gathers up in both hands. De Haseth Möller and Scholten have advanced the tantalizing hypothesis that the work may have served as a wedding gift for the artist's own marriage to Sibilla Rusmair, which occurred sometime before 1559, and the authors tentatively connect it to a seated Venus 'placed in a small case' listed in the inventory of Paludanus's widow in $1582 .{ }^{41}$ Even if Paludanus designed the alabaster to commemorate his wedding, the Greek inscription espousing the erotic nature of Aphrodite nevertheless communicates the universal forces of love: be they generative or unbridled and dangerous. ${ }^{42}$ Like Aphrodite, Eros, especially as represented by Praxiteles, was considered the embodiment of love itself in antiquity, whose power could reach beyond the confines of death. ${ }^{43}$ These concepts of love - concepts developed in relation to works of art - and the irrepressibility of carnal desire also find their way onto the frame of Jan Gossaert's Venus and Cupid (1521), possibly made for Philip of Burgundy, with its ironic inscription that reads: 'Shameless son, you who are inclined to torment men and gods, you do not even spare your own mother: cease, lest you be destroyed'.44

Paludanus's Aphrodite and Eros transcends any fixed narrative moment and is closely related to a painting - a collaboration between Michelangelo, who provided the cartoon, and Pontormo - that showcases the physical and incestuous kiss between Venus and Cupid (fig. 11). The painting became so famous in Europe that even Paludanus's brother Hendrick, who spent most of his career in Italy, imitated it. ${ }^{45}$ As Giorgio Vasari notes, this painting, datable to c. 1532, was originally displayed in 'the center of a chamber' in the home of the Florentine Bartolomeo Bettini, together with images of poets 'who have sung of love in Tuscan prose and verse'..$^{6}$ Benedetto Varchi, responding to the visual force of the painting's imagery in his Due lezzioni (1549), exclaimed that in antiquity 'men fell in love with marble statues, as happened to the Venus of Praxiteles', while today 'the very same happens all day long in the Venus designed by Michelangelo'. ${ }^{47}$ For Varchi, the painting competes with antiquity in awakening in the viewer the emotional and physiological effects of lust and the desire for possession. Vernacular verse also celebrated the power of the visual arts as an erotic inducement. Boccaccio's Amorosa visione (editio princeps 1521) vividly describes a series of wall paintings (istorie) illustrating various amorous subjects, one of which (in canto 19) is a scene of Mars and Venus disclosed by Vulcan. ${ }^{48}$ The poet relates how the surrounding gods gaze intently at the naked bodies of the couple and, overcome by erotic fascination, emulate their adulterous act. It is not irrelevant that in 1543 , the writer Anton Francesco Doni, addressing a letter to Michelangelo about his marble personification of Aurora in the Medici Chapel, declared that the sculpture 'makes you leave the most beautiful and divine woman you could ever see, in order to embrace and kiss' the work. ${ }^{49}$

Paludanus's statuette also indulges the viewer. The image of Aphrodite and Eros kissing further invokes the Pygmalion myth as described in Ovid's Metamorphoses, whichisrich in its exchanges between the senses, especially vision and touch (notably kissing), and their transforming powers. The

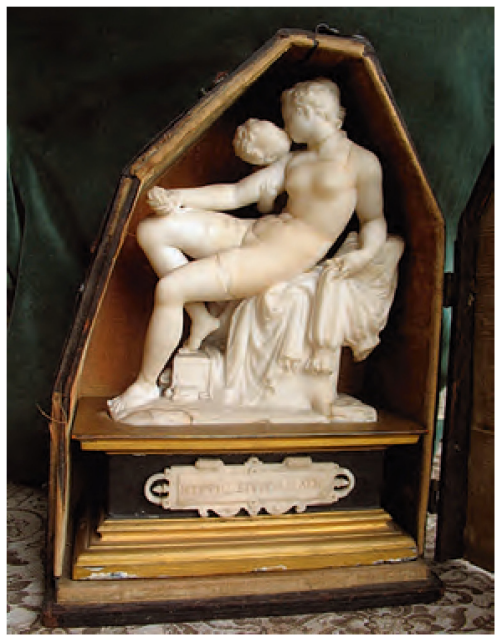

9

Paludanus (Willem van den Broecke), Aphrodite and Eros, 1559 , alabaster, h. 25 $\mathrm{cm}$, Belgium, private collection (photo: Léon Lock, Brussels)

10

Paludanus (Willem van den Broecke), Aphrodite and Eros (back view), 1559, alabaster, h. $25 \mathrm{~cm}$, Belgium, private collection (photo: Léon Lock, Brussels)

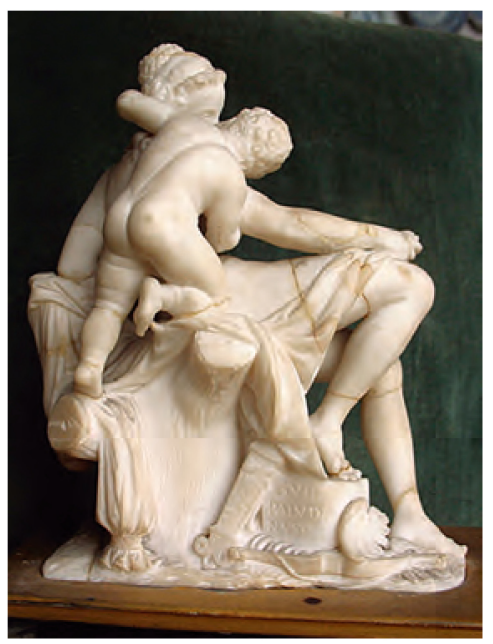




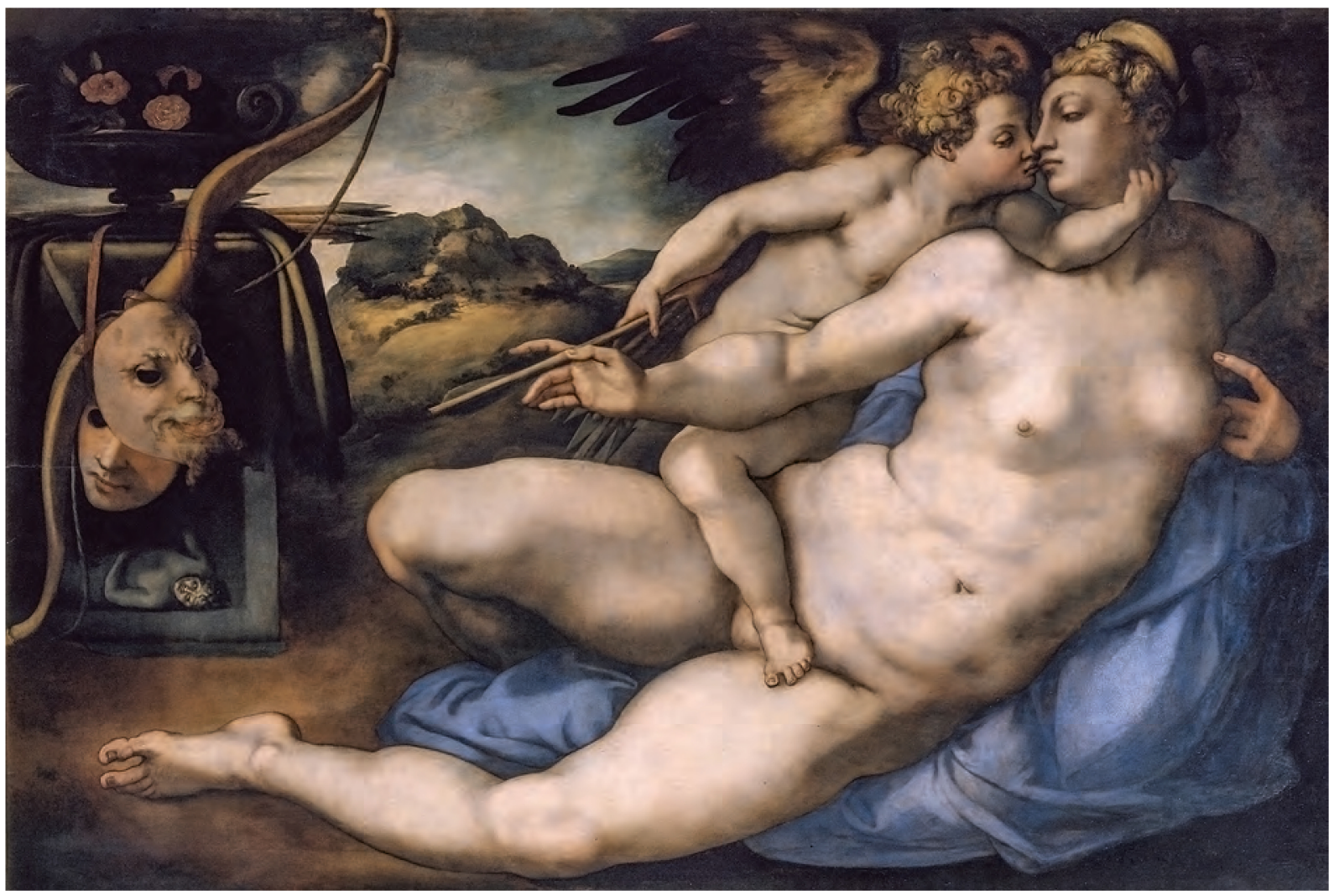

11

Jacopo Pontormo (after a design by Michelangelo Buonarroti), Venus and Cupid, c. 1532, oil on panel, Florence, Galleria dell'Accademia (photo: courtesy of Wikimedia Commons)
Roman poet explains how the sculptor Pygmalion, on completing his ivory statue, looks in admiration and is inflamed with love for this semblance of a form..$^{\circ}$ Venus answers his prayers and rewards the sculptor's technique by bringing his creation to life, a miracle that is accomplished through kiss and touch: Again he kissed her, and with his hands also he touched her breast. The ivory grew soft to his touch, and its hardness vanishing, gave and yielded beneath his fingers'. ${ }^{1}$ The image of the kiss becomes a synecdoche for the full sensory experience of the work of art - from its fabrication to its haptic experience..$^{2}$ The kiss is also one of the greatest expressions of desire and consummation in Ronsard's poetry, an emblem of his seductive verse. Poem 192 from Les amours de Cassandre describes the poet's dream of a passionate kiss with his lover, where he receives her 'lovely white ivory' (bel ivoire blanc) body and 'her flickering tongue' (sa langue frétillarde). ${ }^{53}$ Ronsard and other poets of the Pléiade imitated the genre of lascivious kiss poems (basia) composed by the Dutch-born NeoLatin poet Janus Secundus (1511-1536), who was also a connoisseur of French sculpture and a practiced medalist. Secundus's Basia $(1539 ; 1541)$ remained largely outside of moral or allegorical concerns and instead flaunted the power of poetry in their range from sensual to lewd and often physically aggressive descriptions of kissing. In the sixteenth century, his poetry created a tension with a moralizing system as it cultivated a new audience appreciative of lascivious verse while using humor to offend the detractors of his literary style. ${ }^{4}$ The same can be said for the alabaster by Paludanus, 
in which the kiss denotes enlivening artifice as much as it rivals poetry in its sensual and sexual charm. It is no coincidence that Paludanus was closely associated with the star Antwerp painter Frans Floris (1519/1520-1570), who also promoted erotic imagery in his works. The kiss features prominently in Floris's Feast of the gods from c. 1555-1560 (fig. 12), in which certain gods forcibly encourage their female companions to imbibe while other scantily dressed couples share mutual physical pleasure. ${ }^{55}$ Viewers of Floris's painting, like those of Paludanus's alabaster, would have readily drawn an analogy between the image of kissing and Neo-Latin and vernacular verse, a pretext for inviting the viewer's sexual involvement. What emerges is a new erotic in art and poetry that is purposely transgressive and poses a challenge to an established moralizing tradition.

The emergence of an affective beholder who desires to possess the work of art in place of an absent beloved comes to the fore in Lucas de Heere's Den Hof en Boomgaerd der Poësien (The garden and orchard of poetry), published in $1565.5^{56}$ In numerous poems dedicated to the arts, De Heere, who was also an artist and a pupil of Floris, commends the ability of painters to create vivifying artifice. ${ }^{57}$ His sonnet dedicated to a painting by Willem Key (1516-1568) stages a dialogue between two men who extoll the beauty of a reclining nude woman..$^{8}$ She at first appears asleep, stirring
12

Frans Floris, Feast of the gods, c. 1555-1560, oil on panel, Graz, Universalmuseum Joanneum, Alte Galerie (photo: museum)

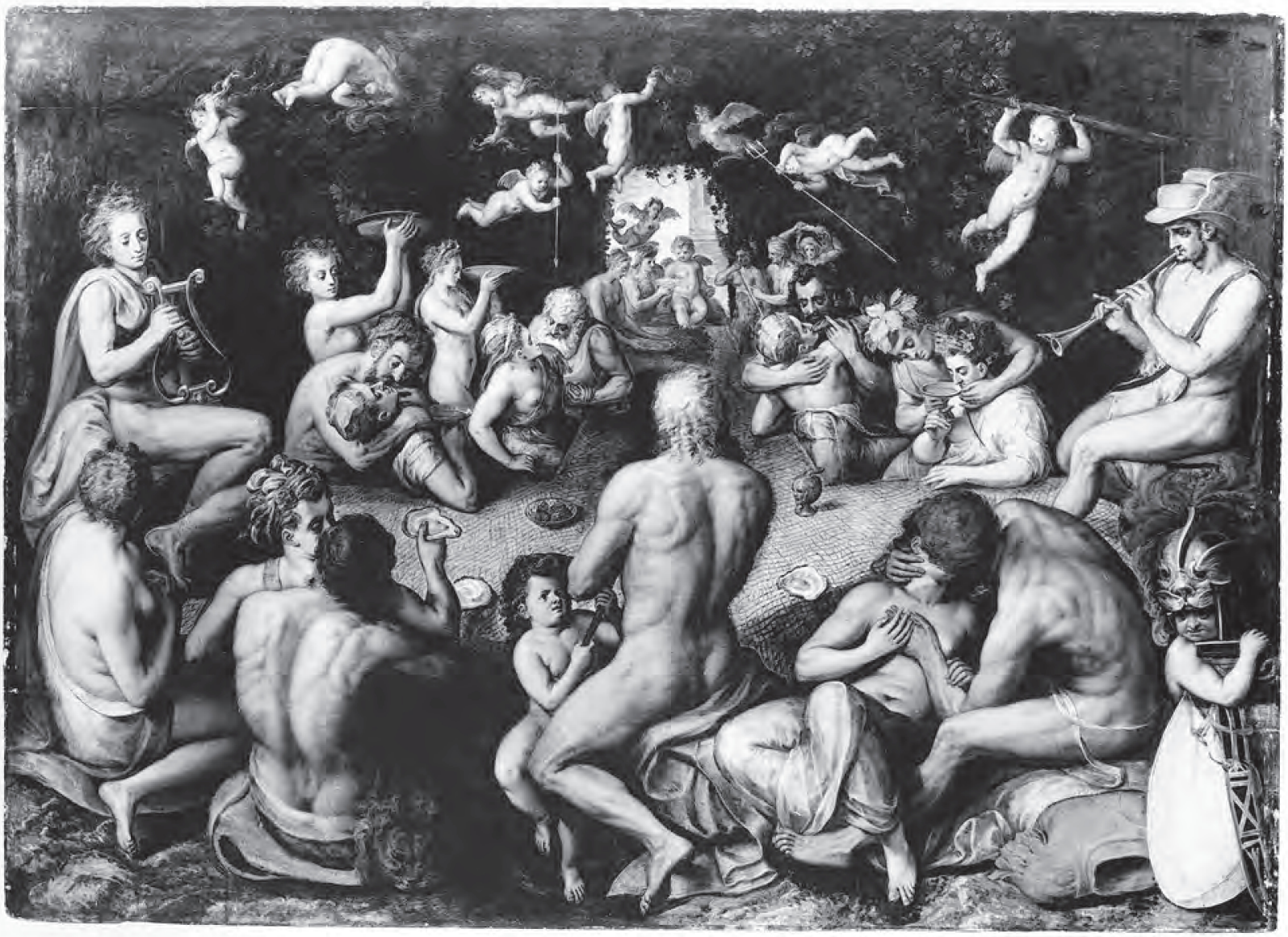




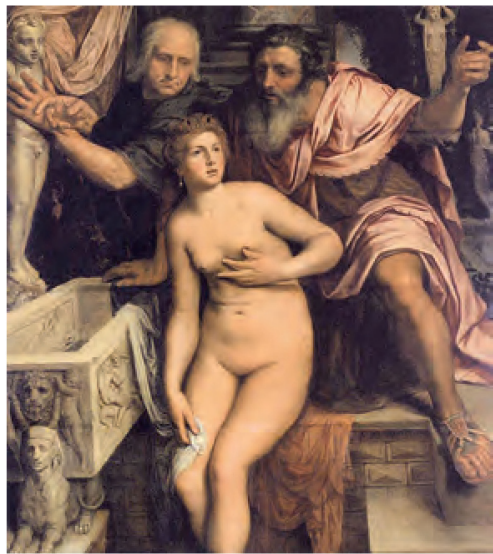

13

Willem Key, Susanna and the elders, 1546 , Oil on panel, Pommersfelden, Schloss Weissenstein (photo: work in the public domain) slightly, but one interlocutor then sees her eyes are open. As they approach, neither experiences any sense of shame (Van haer bi te commen niemant van ons en schame); only then do they realize she is a painting by Key. Still, according to De Heere's poetic imagination, they insist on its veracity: the painting is so true to life (soo wel is gheschildert naer d'leuen). One of interlocutors even needs empirical proof: 'It is painted; feel it, give credence to your hand'.59 The beauty of the nude draws them in while Key's artifice confounds their sensibilities between fiction and reality, paint and flesh. Although De Heere draws on a neo-Petrarchan lyric tradition that celebrates the seductive power of art, his sonnet celebrating Key's nude simulacrum is anything but a routine literary exercise.

Jonckheere has rightly associated De Heere's sonnet with Key's portrayal of female nudes in several of his works, including his magnificent Susanna and the elders (fig. 13), dated 1546 (Pommersfelden, Schloss Weissenstein), a painting that appeals to various senses and artistic mediums. ${ }^{60}$ One of the elders who spies on the nude Susanna grabs the chest of a marble peeing putto, a fountain ornament, while Susanna attempts to cover one of her breasts. This gesture of modesty mimics the statue Venus pudica, thus invoking the paragone between Susanna's pictorial beauty (and the desire to possess it) and that of the ancient marble by Praxiteles. ${ }^{61}$ The

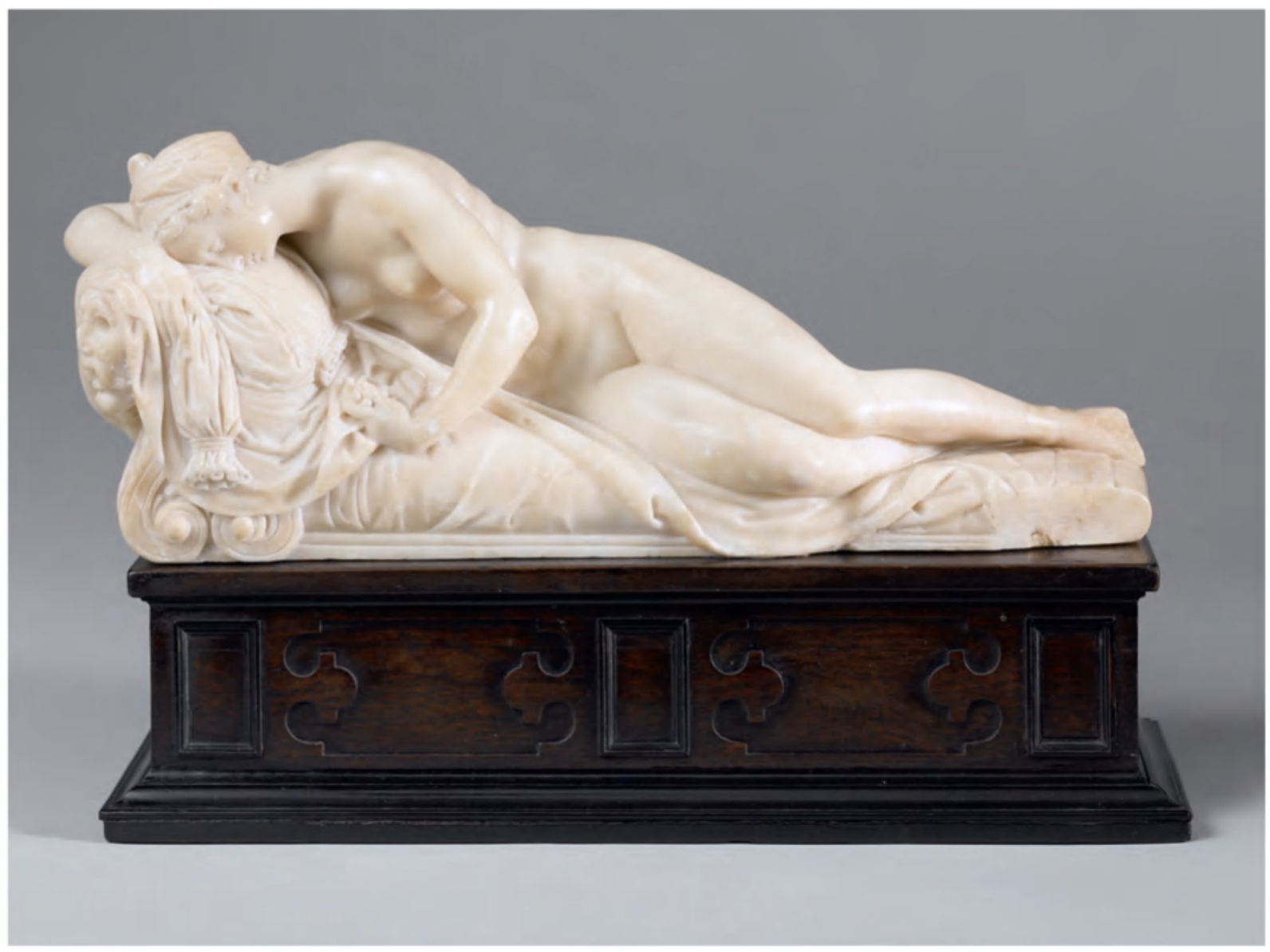


peeing putto, ubiquitous in Renaissance art, can connote a range of verbal and visual puns, often bawdy, as well as the liquid and seed-laden nature of prolific semen' as Patricia Simons suggests. ${ }^{62}$ Here, voyeurism slips into excessive fantasies coupled with a yearning for physical embrace and ejaculatory release, perhaps alluding to the stain on the Cnidian Venus. Key's painting seems to exemplify De Heere's primary thesis in Den Hof, that painting's sweet eloquence supplants poetry in representing universal experiences related to nature and the human condition. ${ }^{63}$ The same can be said of Paludanus's Aphrodite and Eros, which may have served as a go-between, an object defining the effects of desire and magnifying a passionate bond between lovers, spouses, and collectors alike.

Equally provocative and inviting the viewer's involvement is Paludanus's Sleeping nymph (c. 1560), which measures 12.5 centimeters high (figs. 14, 15) ${ }^{64}$ The highly popular image of the sleeping nymph was frequently used in different Renaissance contexts in combination with such themes as lust, continence, fecundity, and inspiration. ${ }^{65}$ The admonition of silence was also a commonplace in Renaissance art and poetry, as with the inscription in Lucas Cranach the Younger's Nymph of the fountain (c. 1545-1550): FONTIS NYMPHA SACRI SOMNUM NE RUMPE QUIESCO (I am the nymph of the sacred spring. Do not disturb my sleep for I am at rest) (fig. 16). ${ }^{66}$ The origins
14

Paludanus (Willem van den Broecke),

Sleeping nymph, c. 156o, alabaster, h. $12.5 \mathrm{~cm}$, Amsterdam, Rijksmuseum (photo: copyright Rijksmuseum, Amsterdam)

15

Paludanus (Willem van den Broecke), Sleeping nymph (front view) c. 156o, alabaster, h. 12.5 cm, Amsterdam, Rijksmuseum (photo: copyright Rijksmuseum, Amsterdam)

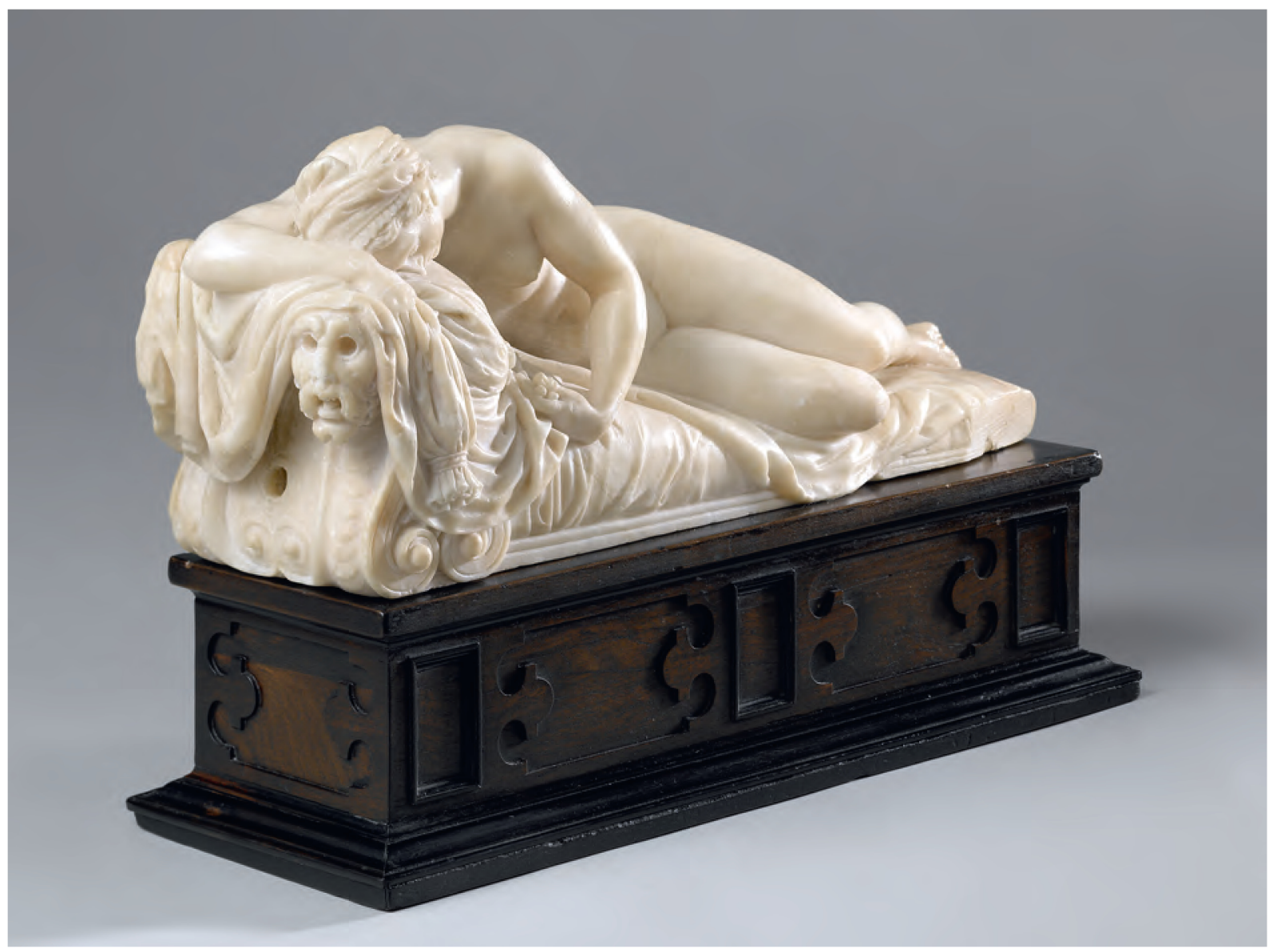




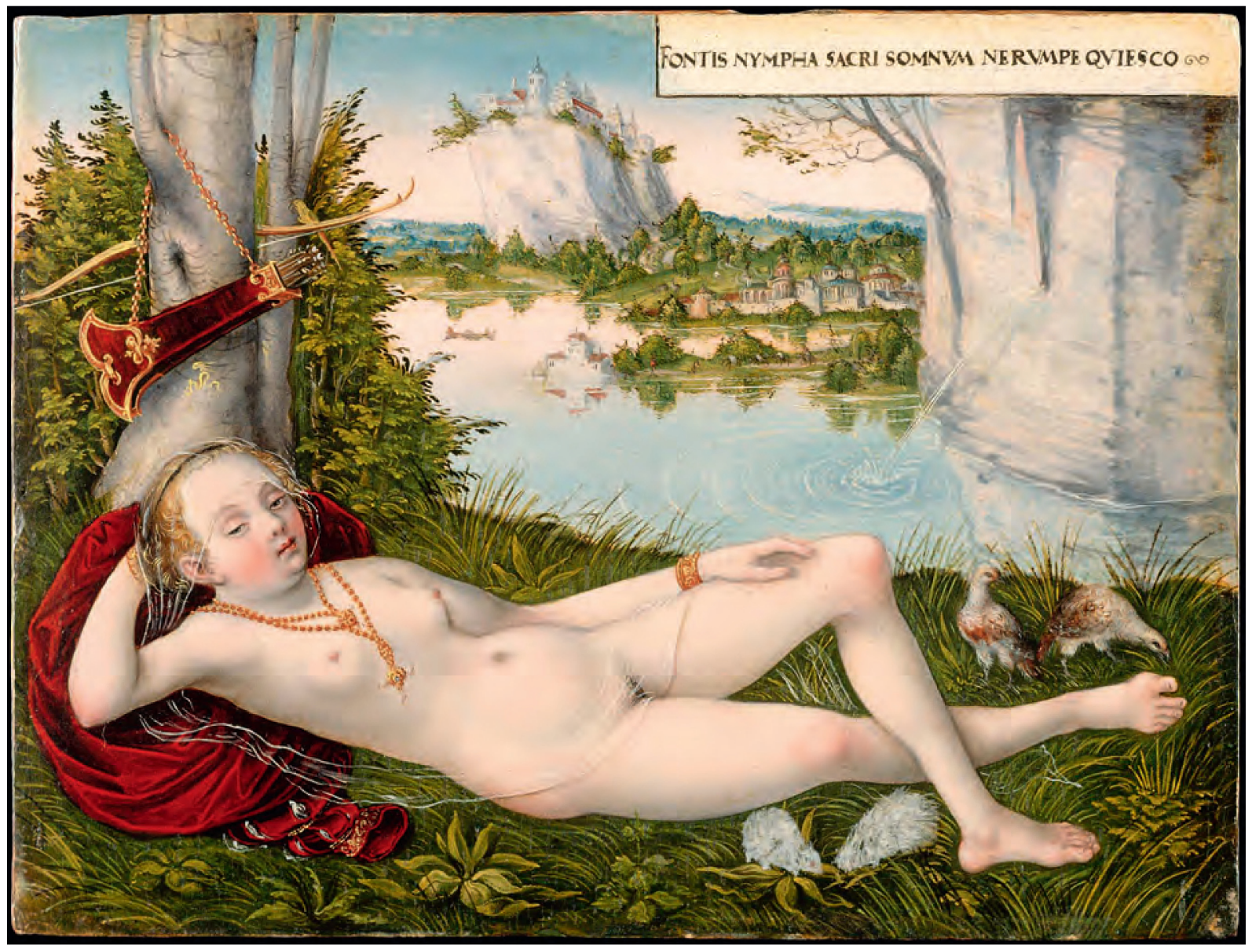

16

Lucas Cranach the Younger, Nymph of the

fountain, c. $1545^{-1} 55^{\circ}$, oil on panel, New York, Metropolitan Museum of Art (photo: courtesy of the Metropolitan Museum of Art Creative Commons license) of such inscriptions can be traced to an epigram, supposedly ancient but in actuality a humanist invention of the 1470 , which was devoted to a sleeping nymph that allegedly graced a fountain on the banks of the Danube. In Renaissance art and poetry, the sleeping nymph stood as a timeless artistic force whose 'voice' ostensibly repudiates the viewer's intrusion and speech yet whose status as a beautiful object invites seduction. ${ }^{67}$

Paludanus also encourages the beholder to savor his alabaster in silence in order to spark the imagination and create a subjective narrative. Such an encounter is staged in Sonet 2 of Van der Noot's Het Bosken, which is a refashioning of Petrarch's Una candida cerva sopra l'erba. ${ }^{68}$ The poet spies on a doe, an animal sacred to the goddess Diana but also an emblem of the poet's object of desire, with the stalking or hunting of the creature analogous to amorous pursuit; Van der Noot writes: 'A spotless hind I saw, white of color (Een hiende reyn sach ick wit van colure) (...) lying gracefully by a river pure'. The inscription 'No man may touch me' (Niemant en roer my) is inscribed on the jeweled chain around her neck, and the poet vows to let no brute harm her, although he is compelled to follow her, forsaking all else. ${ }^{69}$ The poet becomes obsessed with the object of his own creation: the loveliness of the doe/woman stands as a metaphor for his own enthralling 
lyrics. In Sonet 5, moreover, Van der Noot judges the beauty of a nymph to rival that of Venus, and the loveliness of the flowering meadow in which she rests to surpass that of any painting or tapestry. ${ }^{70}$ Van der Noot therefore poses a challenge to artists to make a creature more desirable than that of the poet, whose soul, at first sight of the nymph, 'has pined for her love' (Tsynts desen tyt queelt myn siele om heur minne).

It is within such artistic and poetic contexts that Paludanus carved his alabaster sleeping nymph, enabling it to be admired from multiple viewpoints. From above, the nude body of the nymph, which rests on a bed, takes precedence, her face obscured. From the side, one notices the nymph's closed eyes, while the cloth under her seems to have just been removed to reveal her body. It is only when studying the object from the front that the mask comes into full view, confronting the viewer and making one selfconscious of a voyeuristic gaze. In the absence of an inscription, the mask before Paludanus's sleeping nymph lends to the overall psychology of the work. The mask features as an ornament in numerous Italian and French works of art: for example, in Michelangelo and Pontormo's Venus and Cupid, signaling, perhaps, that the love Venus offers is only a simulacrum or falsehood. ${ }^{71}$ Venus's role in the Florentine painting seems to combine and contrast vernacular concepts of love with those discussed by Lucretius in book 4 of his De rerum natura: sensations of sexual desire that drive people to visual and physical gluttony and eventual ruin. Lucretius states that Venus, manifest as a bewildering and insatiable lust, mocks wounded lovers with insubstantial images, much like a mirage, which scatters in the winds..$^{72}$

A number of Renaissance humanists, including Angelo Poliziano and Erasmus of Rotterdam, define the mask (larva) as denoting an empty fear or preoccupation that induces obsessive panic. ${ }^{73}$ Highly relevant is the satyr mask below the figure of Michelangelo's Night in the Medici Chapel (fig. 17). Paludanus's nymph holds poppies in her hand, surely a quotation of the same opiate flower that induces sleep found under Michelangelo's personification. ${ }^{74}$ Charles Dempsey has demonstrated that in the context of the Medici Chapel - the burial space of the ambitious Medici dukes who died too young to fulfill their worldly aspirations - the mask denotes generically earthly and sensual obsessions doomed to frustration. ${ }^{75}$ In Paludanus's work, the mask invokes erotic nightmares: the narcotic slumber of the nymph brings forth nightmares of sexual obsession and domination, of a soul possessed and anguished by erotic fantasies - not just for the subject (the nymph), but for the viewer as well. In his famous poem Les daimons from the collection Les hymnes, published in 1555 , Ronsard writes how tiny demons conceal themselves behind false masks: 'under the mask of illusory disguises (masquez de vaines feintes), [they] fill human hearts with the utmost dread. ${ }^{76}$ Demons are rarified airy spirits that nonetheless 'partake of the nature of both God and human beings: of God in that they are immortal, of humans in that they are filled with every passion' (De toutes passions): desire, fear, love, and hate. ${ }^{77}$ The poet further explains that these demons could deceive and transform themselves into many things, like 'nymphs' and 'satyrs': disguises that are visible to our imagination when we are most susceptible..$^{78}$ Given the popularity of Ronsard's poetry in Flemish humanistic circles, it follows that the mask before Paludanus's sleeping 


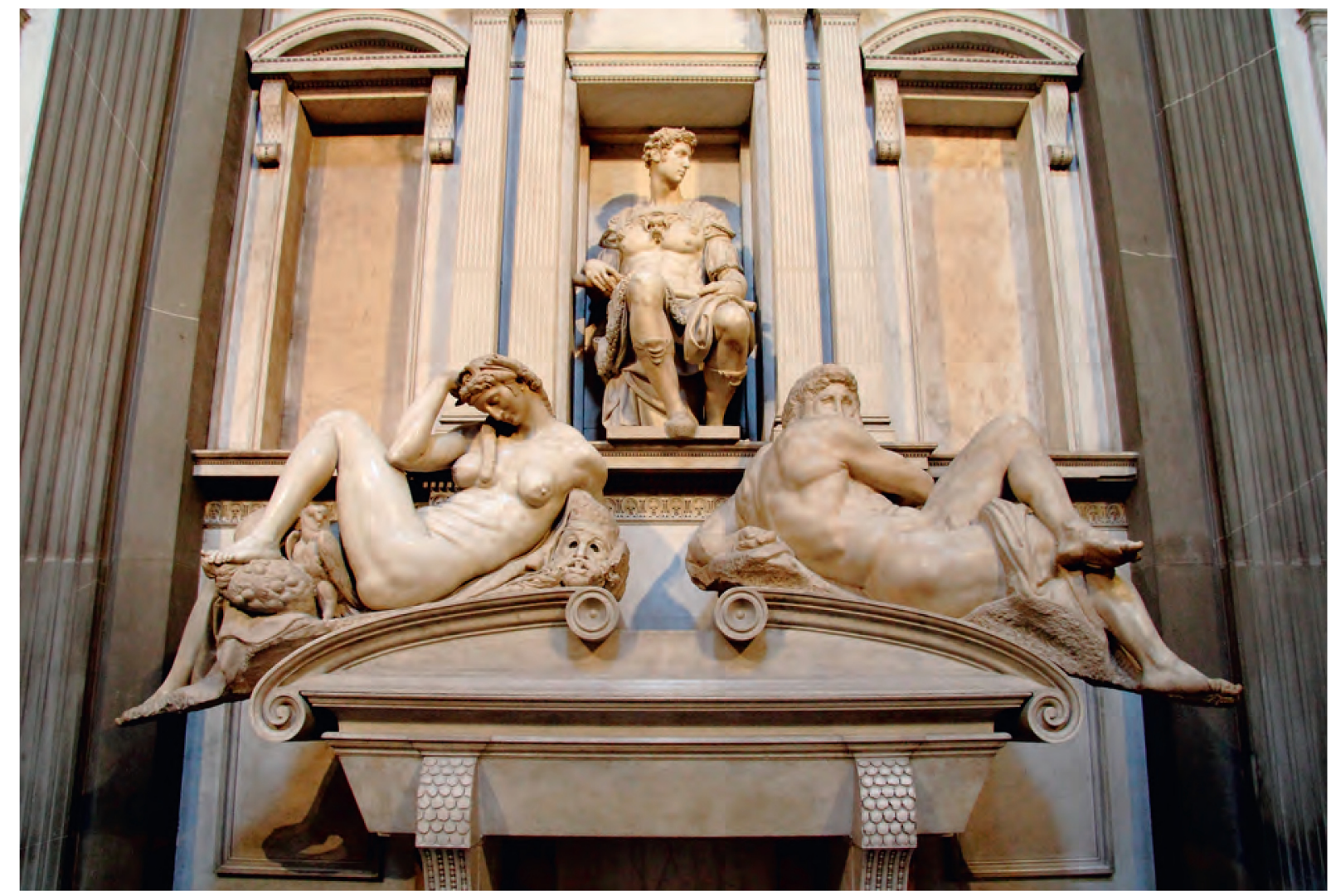

17

Michelangelo Buonarroti, Tomb of Giuliano de' Medici, 1524-1534, marble, Florence,

Medici Chapel, San Lorenzo (photo: courtesy of Wikimedia Commons) nymph incites nympholeptic terrors, or those sensual and sexual obsessions that torment the viewer's heart and assail one's imagination. Paludanus gives his alabaster a 'hidden reserve' of allusive energy whose potential is released when images and texts are brought together in the viewer's mind. ${ }^{79}$ The yearning to touch and possess the sleeping nymph, in the form of a beautiful alabaster, can evolve into an insatiable desire.

Thoroughly poetic, Paludanus's sculptures discussed above invite deliberation on the paradoxical nature of love and its sometimes maddening effects. The medium of alabaster, by aligning itself with the vernacular body and inducing a sense of touch, helped condition a newly emerging experience for works of art in the Netherlands. When analyzed together with the amorous conceits expressed by the leading lyric poets of his age, Paludanus's alabasters seem to court idolatry. In 1522 the German iconoclast Andreas Bodenstein von Karlstadt admitted his desirous addiction to images, the pull of the idol, realizing how firmly and deeply images are seated in my heart' and leading him to call for the removal or destruction of images from churches. ${ }^{80}$ By contrast, Antwerp in the second half of the sixteenth century celebrated the art object in the secular arena as a vehicle to express and promote desire. In light of the onset of iconoclasm in 1566, the erotically themed works of Paludanus and his contemporaries became only more coveted and prized by humanists and collectors for their rhetorical and sensual appeal. 


\section{Notes}

My warmest thanks to E. Matt Kavaler for generously sharing detailed images of Paludanus's alabasters with me and for our engaging discussions on his work, which greatly shaped my thinking. I would also like to thank Frits Scholten and Aleksandra Lipińska for kindly providing images for publication and for their encouragement. The two anonymous reviewers of my manuscript also offered thoughtful suggestions.

1 See Freedman 1999 and Jansen 1996.

2 On the issue of touch and sensual engagement with regard to small-scale sculpture in the Italian Renaissance, see Johnson 2012. Furthermore, Anthony Grafton, in his discussion of the premium that Renaissance humanists put on commerce (commercium) - to make precious things available, especially the translation of ancient texts - observes that luxurious manuscripts and bound books had a 'sensual, even erotic appeal' in their production and reception (Grafton 1997, 15).

3 On Titian's colorito technique, see the primary study by Rosand 1981 .

4 See Campbell 2004, 45-52.

5 The most recent studies on Paludanus, all with comprehensive bibliography on the sculptor, are De Haseth Möller \& Scholten 2013; and Lipińska 2015, 81-89. See further Woods 2007, 43-52.

6 See De Haseth Möller \& Scholten 2013, 153 .

7 The secular works under investigation in this paper have most recently been studied by De Haseth Möller \& Scholten 2013 and Lipińska 2015, 81-85.

8 Lipińska 2013 and Lipińska 2015, 17-43, on the physical properties and meanings of alabaster as a sculptural material.

9 'De borstkens van albaste'. Text and translation are from Jongenelen \& Parsons 2008, 246, Sonet 9, verse 12.

10 Ariosto 1976, 10.96.1-2 (218). For a discussion of Ariosto's strategy to eroticize as well as to render Angelica 'remote and inanimate' in these passages, see Finucci 1992, 123-124. At the heart of these lines is the paragone, or Ariosto's ability to sway his audience with an image of beauty, to establish through words a representational truth that is more persuasive than that achieved by the visual arts. The first French translation, into prose by Jean Martin, of the Orlando furioso was published in Lyon in 1543 .

11 Elizabeth Cropper has demonstrated that, coinciding with the emergence of an 'affective beholder' in the 16th century, were images of beautiful women that functioned as 'synecdoches' for beautiful painting, whereby the beholder aligned his desire for one with the desire for the other according to the conventions of lyric poetry; see Cropper 1995 and Cropper 1986. See further Campbell 2004 on the affective subject and works of art as objects of desire.

12 See Ramakers 2012, esp. 138-151. For the key literary personalities involved in the reception, circulation, and imitation of French poetry in the Netherlands, see also Bostoen 1987 and Prandoni 2014.

13 Recently, Keizer \& Richardson 2012 have emphasized the importance of the vernacular in the art and poetry of the Netherlands for developing a new, assimilative, and enriched form of expression based on select choices from the ancient and the modern, the familiar and the foreign.

14 For biographical information on Paludanus, see De Haseth Möller \& Scholten 2013 and Lipińska 2015, 81-90.

15 De Haseth Möller \& Scholten 2013, 153. 16 See Lipińska 2015, 84.

17 De Haseth Möller \& Scholten 2013, 164.

18 Antwerp rhetoricians proclaimed their allegiance to Charles V in 1519 with triumphal celebrations, which included imagery, performances, and inscriptions that revolved around the terms fudes et amor, or the fidelity and love of Antwerp towards its sovereign; see Waite 2000, $57^{-}$ 58.

19 De Haseth Möller \& Scholten 2013, 158.

20 By the 16 th century, books were part of a system of gift and obligation, whereby the process of giving and receiving was embedded with multiple meanings. Erasmus of Rotterdam called books 'presents for the mind' and 'keepsakes' for his erudite friends, whom he describes as 'many jewels in one small book'; see Davis 1983 , esp. 77 .

21 De Haseth Möller \& Scholten 2013, 160163.

22 Maerten van Heemskerck sketched an ancient example (now lost) while he was in Rome between $153^{2}$ and 1535 , for which see De Haseth Möller \& Scholten 2013, 161; and Barkan 1999, 145 .

23 Parmigianino's Madonna of the long neck (1534-1540) also juxtaposes the beauty of the Madonna (based on vernacular poetic ideals) to the swelling curves and slender neck of the amphora held by one of the angels; see Cropper 1976.

24 'Ch'è la più bella antigità che li fuse'.
The letter is reproduced in Trevisani \& Gasparotto 2009, 317. Around 1500, Antico created the model for his two bronzes of Atropos (one in the Kunsthistorisches Museum, Vienna; and the other in the Victoria and Albert Museum, London), which appears to be based on the same ancient statue as Paludanus's Aphrodite drying herself.

25 Boccaccio 2011, $382-385,3.22$; and see the discussion of this passage in relation to erotically charged imagery in the Italian Renaissance by Turner 2008, esp. 181-182.

26 Pliny the Elder, Natural history, 36.20 , translated in Pollitt 1990, 84. See also Paton 1918, epigrams 159 and 16o, where the Greek poets describe how Praxiteles carved 'love-longing in a stone, and Aphrodite herself asks, Where did Praxiteles see me naked?'.

27 Charles Avery has duly noted that questions of artistic precedence with regard to the works of Paludanus and Giambologna 'should not be solved by a rule of thumb which always gives the priority and credit to Giambologna, brilliant and inventive though he was'; see Avery 1987,48 .

28 See Buijnsters-Smets 1995, 191-200. The primary focus by art historians has been on the landscape in this painting, which shows an accurate panorama of the city of Genoa; see most recently Galassi 2014. Galassi suggests that the patron of Massys's painting was the Genoese banker and poet Ambrogio Di Negro (1519-1621), who visited the Netherlands on several occasions and whose family owned the Villa Durazzo and Villa Lo Scoglietto featured in the painting.

29 See the insightful discussion on the importance of Fontainebleau for northern artists, including Jan Massys, in Kavaler 2008, esp. 204. Kim 2014, 25-33, revises traditional art-historical uses of the term 'influence' with regard to the mobility of artists, who ultimately acted as multisensory arbiters of the familiar and foreign in the artistic environments they encountered. Massys was an artist who certainly traveled, although documents on his whereabouts outside of Antwerp during his exile (1544-1555) are scare. Nevertheless, his creative method of artistic imitation - like that of Paludanus - obeys principles of literary theory and practice in the 16 th century, for which see Cave 1979, 35-77; Pigman 1980; and Ackerman 2000, among other important studies.

3o The relevant passages are discussed by 
Muller 1982, esp. 241; and see further Lehman 2007-2008, esp. 96-98.

31 Jonckheere zo13b discusses how those involved in the image debates in the Netherlands after the rage of iconoclasm in 1566 opposed the relative materiality of painting to an emphasis on the physical and natural. Notably, Freedberg 1982 (esp. 135) observes that the condemnation of lascivious imagery by the Council of Trent and by Netherlandish theologians calls to mind numerous works by Jan Massys.

32 In the case of Ronsard's use of the Petrarchan lyric, see Castor 1973. It should be noted that Paludanus himself knew Italian, confirmed in a letter he wrote to the secretary of the Duke of Alba; see De Haseth Möller \& Scholten 2013, 167.

33 See, for example, Les amours de Cassandre, poems 23 and 137 (in Ronsard 1974, 34, 93); and further Weber 1997. See also Lipińska $2015,33-34 ; 33^{8 n} 74$; and Lipińska 2013, 104-106, for other examples of alabaster and the poetic body.

34 See Sonets pour Hélène (1578), poem 61 (in Ronsard 1974, 311-312). See also McGowan 2015 for Ronsard's poetry and its relationship to the visual arts.

35 A commonplace in medieval and Renaissance vernacular verse was the idea that spiritual, pneumatic forces (spiritelli d'amore) could enter through the eyes and 'figure' themselves in the lover's imagination; see Agamben 1993, 102-110.

$3^{6}$ See Lipińska 2013, 96; and Lipińska 2015, 29-30, for the tactile sensations produced by alabaster and its connection to flesh.

37 See Kohl et al 2014. The material nature of alabaster was long admired for its special properties, including the power to gain friendship; see Lipińska 2013, 94.

$3^{8}$ On Meit's Judith, see Burk et al. 2006, 7679; and Lipińska 2015, 29-30.

39 For this work and other versions of Lot and his daughters, see Lipińska 2015, 257260.

40 See De Haseth Möller \& Scholten 2013, 158-159; and Lipińska 2015,84.

41 De Haseth Möller \& Scholten 2013, 158.

42 The image of Eros and Aphrodite kissing one another relates to Ovid's Metamorphoses (10.525-26), where Eros accidently inflicts the wound of love on his mother, scratching her breast with his arrow and causing Aphrodite to become desirous of the mortal Adonis.

43 See Pliny the Elder, Natural history, 36.20 (in Pollitt 1990, 84-85): 'There is another Eros by [Praxiteles], this one nude, in Parium, the colony on the Propontis, which is equal to the Aphrodite at Knidos both for its fame and for the injury it suffered; for Alketas the Rhodian fell in love with it and also left upon it the same sort of trace of his love'. See also Paton 1918 , epigrams $167,211,212$, and 213 , for the persistence of Eros's power in sleep and death as it relates to ancient works of art.

44 Translated in Cat. New York, 62. Bass 2016, 109-111, emphasizes that Gossaert's frame was detachable, affording primacy to the 'sensual struggle' of the visual imagery.

45 See the entry by Jonathan Katz Nelson in cat. Florence 2002, 197-198. Considering the myriad copies and variations of the composition, Bellucci \& Frosinini 2002 argue convincingly that Michelangelo's cartoon was itself reproduced in Pontormo's workshop, both in its entirety and in smaller, separate segments.

46 See cat Florence 2002, 14.

47 Turner $2008,182$.

48 See my review of the exhibition catalogue, Fiorenza 2004.

49 Cited in Turner 2008, 182. In 1576 Emanuel Philibert, Duke of Savoy, presented to Elector Augustus of Dresden alabaster copies of the four personifications from Michelangelo's Medici tombs in San Lorenzo, Florence. These gifts testify to the popularity and 'divine' status of Michelangelo in northern Europe, and to the use of art in diplomacy; see Lipinska $2015,255^{-25} 6$.

5o Ovid 1984, 10.252-253: 'miratur et haurit/ pectore Pygmalion simulati corporis ignes. On the Pygmalion theme, see further Stoichita 2008 and Bolland 2000. Lipinska 2013, 106, discusses how literary texts, both ancient and modern, with their references to the sensuality of the Pygmalion myth, "contributed to shaping the reception of sculpture generally, and the reception of cabinet sculpture in precious materials in particular'.

51 Ovid 1984, 10.282-284: 'admovet os iterum, manibus quoque pectora temptat:/ temptatum mollescit ebur positoque rigore/ subsidit digitis ceditque:

52 See Lipińska 2013, 96, for indications of touching and kissing of alabaster and ivory works of art, especially in the arena of religious practice.

53 Les amours de Cassandre, poem 192 (in Ronsard 1974, 123); trans. Ronsard 2002, 23 , poem 192.

54 See Price 1996, 55-73; and Price 1992.

55 I also discuss Floris's Graz painting in relation to the genre of the basia in Fiorenza forthcoming.

56 De Heere 1969 .

57 As Walter Melion has shown, De Heere's poems entertain the Pygmalion myth as a lyric conceit, uniting the theme of the absent beloved with the theme of the seductive power of pictorial artifice'; see Melion 2001, esp. 160-162.

$5^{8}$ De Heere 1969, 54, poem 47. Both Weissert 2011 (6on28) and Ramakers 2009 (181-182) provide a translation and discussion of the poem.

59 'Tis schilderye, tast wilt $u$ hant gheloof gheuen'.

6o See Jonckheere 2011, 150; and Jonckheere $2013 a, 116$.

61 Key's visual reference to the ancient statue was first noted by Urbach 1995 .

62 Simons 2009, 360.

63 Borrowing from the Horatian doctrine that successful poetry combines profit with pleasure (dulce et uile), De Heere claims that painting is the most 'useful' (orborelick) and 'delightful' (vermakelick) of all the arts; De Heere 1969, 109. Melion 1991, 129-142, provides an informative discussion of the artistic context of $\mathrm{De}$ Heere's text. See also Ramakers 2009, 178 .

64 See De Haseth Möller \& Scholten 2013 , 159-160; Lipińska 2015, 84 .

65 See, for example, Kurz 1953; Bober 1977; MacDougall 1975; Barkan 1999, 233-243; and Curran 2007, 171-176.

66 The translation is Liebmann 1968, 435 n9.

67 See Barkan 1999, esp. 241-242.

68 Petrarch, Rime sparse, poem 190 (in Durling 1976, 336-337).

69 Jongenelen \& Parsons 2008, 241, Sonet 2.

70 Jongenelen \& Parsons 2008, 243, Sonet 5 .

71 See Campbell 2004, 265-266; and Cropper 2006, esp. 53-54.

72 Lucretius 1992, 4.1084-1120. Notably, Lucretius states (4.1101-1104): 'sic in amore Venus simulacris ludit amantis, / nec satiare queunt spectando corpora coram,/ nec minibus quicquam teneris abradere membris/ possunt errantes incerti corpore toto' (so in love Venus mocks lovers with images, nor can bodies even in real presence satisfy lovers with looking, nor can they rub off something from tender limbs with hands wandering aimlessly all over the body).

73 Dempsey zoo1 provides an excellent analysis of the mask in Renaissance art; see pp. 102-103 for classical and vernacular definitions of the mask, especially as it relates to 'eros playing the bogeyman'.

74 The connection of the mask and poppies with Michelangelo's statue was noted by De Haseth Möller \& Scholten 2013, 159. Copies of Michelangelo's personifications in the Medici Chapel circulated throughout Europe, as testified by the 
example cited in $n .49$.

75 Dempsey 2001, 220-231.

76 Ronsard 2002, 147, Les daimons, verses 75-76; and see Dempsey 2001, 105-106, and 126 , for a discussion of Ronsard's poem.
77 Ronsard 2002, 149, Les daimons, verses $113-116$.

78 Ronsard 2002, 155, Les daimons, verses $251-253$.

79 Such a process of allusion as it operates in classical literature is described by Conte 1986,33 .

8o Quoted in Smith 2004.
Bibliography

\section{Ackerman 2000}

J. Ackerman, 'Imitation', in: Antiquity and its interpreters (A. Payne, A.

Kuttner \& R. Smick, eds.), Cambridge 200o, 9-16.

\section{Agamben 1993}

G. Agamben, Stanzas. Word and phantasm in Western culture (R.L.

Martinez, trans.), Minneapolis \& London 1993.

\section{Ariosto 1976}

L. Ariosto, Orlando furioso (C. Segre, ed.), Milan 1976.

\section{Avery 1987}

C. Avery, Giambologna. The complete sculpture, Mt. Kisco 1987.

\section{Barkan 1999}

L. Barkan, Unearthing the past. Archaeology and aesthetics in the making of Renaissance culture, New Haven 1999.

\section{Bass 2016}

M.A. Bass, Jan Gossart and the invention of Netherlandish antiquity, Princeton 2016.

\section{Bellucci \& Frosinini 2002}

R. Bellucci \& C. Frosinini, ‘Un mito michelangiolesco e la produzione seriale. Il cartone di Venere e Cupido', in: cat. Florence 2002, 109-121.

\section{Bober 1977}

P.P. Bober, 'The Coryciana and the nymph Corycia',Journal of the Warburg and Courtauld Institutes 40 (1977), 223-239.

\section{Boccaccio 2011}

G. Boccaccio, Genealogy of the pagan gods, vol. 1, books 1-5 (J. Solomon, ed. \& trans.), Cambridge, MA zol1.

\section{Bolland 2000}

A. Bolland, 'Desiderio and diletto. Vision, touch, and the poetics of Bernini's Apollo and Daphne', Art Bulletin 82 (2000), 309-330.

\section{Bostoen 1987}

K. Bostoen, Dichterschap en koopmanschap in de zestiende eelww. Omtrent de dichters Guillaume de Poetou en Jan van der Noot, Deventer 1987 .

\section{Buijnsters-Smets 1995}

L. Buijnsters-Smets, Jan Massys. Een Antwerps schilder uit de zestiende eeuw, Zwolle 1995.

Burk et al. 2006

J.L. Burk a.o., Conrat Meit. Bildhauer der Renaissance, Munich 2006.
Campbell 2004

S. Campbell, The cabinet of Eros. Renaissance mythological painting and the studiolo of Isabella d'Este, New Haven \& London 2004.

\section{Castor 1973}

G. Castor, 'Petrarchism and the quest for beauty in the Amours of Cassandre and the Sonets pour Hélene', in: Ronsard the poet (T. Cave, ed.), London, 1973, 79-120.

\section{Cave 1979}

T. Cave, The cornucopian text. Problems of writing in the French Renaissance, Oxford 1979.

Conte 1986

G.B. Conte, The rhetoric of imitation. Genre and poetic memory in Virgil and other Latin poets, Ithaca \& London 1986.

Cropper 1976

E. Cropper, 'On beautiful women. Parmigianino, Petrarchismo and the vernacular style', Art Bulletin 63 (1976), 375-394.

\section{Cropper 1986}

E. Cropper, 'The beauty of woman. Problems in the rhetoric of Renaissance portraiture', in: Rewriting the Renaissance. The discourse of sexual difference in early modern Europe (M.W. Ferguson, M. Quilligan \& N. Vickers, eds.), Chicago 1986, 175-190.

\section{Cropper 1995}

E. Cropper, "The place of beauty in the high Renaissance and its displacement in the history of art', in: Place and displacement in the Renaissance (A. Vos, ed.), Binghamton 1995, 159-205.

\section{Cropper 2006}

E. Cropper, 'Caravaggio and the Matter of Lyric', in: Caravaggio. Realism, rebellion, reception (G. Warwick, ed.), Newark 2006, 47-56.

\section{Curran 2007}

B. Curran, The Egyptian Renaissance. The afterlife of ancient Egypt in earty modern Itaby, Chicago \& London 2007.

Davis 1983

N.Z. Davis, 'Beyond the market. Books as gifts in sixteenth-century France', Transactions of the Royal Historical Society 33 (1983), 69-88.

Dempsey zoo1

C. Dempsey, Inventing the Renaissance putto, Chapel Hill \& London 2001.

Durling 1976

R. Durling, Petrarch's lyric poems. The Rime sparse and other lyrics, Cambridge, MA \& London, 1976. 


\section{Finucci $199^{2}$}

V. Finucci, The lady vanishes. Subjectivity and representation in Castiglione and Ariosto, Stanford 1992.

\section{Fiorenza 2004}

G. Fiorenza, review of Cat. Florence 2002, ca. reviews, 16 June 2004 http://www.caareviews.org/reviews/651\#.WW6V58YZOnc.

\section{Fiorenza forthcoming}

G. Fiorenza, 'Frans Floris and the poetics of mythological painting in Antwerp', in: Netherlandish culture of the sixteenth century (E.M. Kavaler \& A.-L. Van Bruaene, eds.), Turnhout forthcoming.

\section{Cat. Florence 2002}

Cat. Florence, Firenze Musei, Venere e amore. Michelangelo e la nuova bellezza ideale (F. Falletti \& J.K. Nelson, eds.), Florence 2002.

\section{Freedberg 1982}

D. Freedberg, 'The hidden god. Image and interdiction in the Netherlands in the sixteenth century', Art History 5 (1982), 133-153.

\section{Freedman 1999}

L. Freedman, "Titian's Jacopo da Strada. A portrait of an "antiquario", Renaissance Studies 13 (1999), 15-39.

\section{Galassi 2014}

M.C. Galassi, 'Topography and mythological transfiguration in two sixteenth-century Flemish cityscapes of Genoa. A painting by Jan Massys and an etching by Anton van den Wyngaerde', in: Portraits of the city. Representing urban space in later medieval and earty modern Europe (K. Lichtert, J. Dunolyn \& M. Martens, eds.), Turnhout 2014, 131-142.

\section{Grafton 1997}

A. Grafton, Commerce with the classics. Ancient books and Renaissance readers, Ann Arbor 1997.

\section{De Haseth Möller \& Scholten 2013}

T. de Haseth Möller \& F. Scholten, 'Paludanus. A humanist sculptor working for Spain', in: Zwischen Lust und Frust. Die Kunst in den Niederlanden und am Hof Philipps II von Spanien (1527-1598) (C. Weissert, S. Poseschel \& N. Büttner, eds.), Cologne 2013, 149-173.

\section{De Heere 1969}

L. de Heere, Den Hof en Boomgaerd der Poësien (W. Waterschoot, ed.) Zwolle 1969 .

\section{Jansen 1996}

D.J. Jansen, 'Strada', in: Dictionary of art (Jane Turner, ed.), London \& New York 1996, vol. 29, 737-740.

\section{Johnson 2012}

G.A. Johnson, In the hand of the beholder. Isabella d'Este and the sensual allure of sculpture', in: Sense and the senses in early modern art and cultural practice (A.E. Sanger \& S.T.K. Walker, eds.), Burlington 2012, 183-197.

Jonckheere 2011

K. Jonckheere, Willem Key (1516-1568). Portrait of a humanist painter, Turnhout zon.
Jonckheere 2013a

K. Jonckheere, Antwerp art after iconoclasm experiments in deconum 1566-1585, New Haven \& London 2013.

\section{Jonckheere 2013b}

K. Jonckheere, 'Images of stone. The physicality of art and the image debates in the sixteenth century', Netherlands Yearbook for the History of Art / Nederlands Kunsthistorisch Jaarboek 62 (2013), 116-147.

Jongenelen \& Parsons 2008

B. Jongenelen \& B. Parsons, "The sonnets of Het Bosken by Jan van der Noot', Spencer Studies 23 (2008), 235-255

\section{Kavaler 2008}

E.M. Kavaler, 'Jacques du Broeucq and northern perspectives on the antique mode', in: Invention. Northern Renaissance studies in honor of Molly Faries (J. Chapuis, ed.), Turnhout 2008, 203-219.

Keizer \& Richardson 2012

J. Keizer \& T.M. Richardson (eds.), The transformation of vernacular expression in early modern arts, Leiden 2012.

$\operatorname{Kim} 2014$

D.Y. Kim, The traveling artist in the Italian Renaissance. Geography, mobility, and style, New Haven \& London 2014

\section{J. Kohl et al. 2014}

J. Kohl, M. Koos \& A. Randolph (eds.), Renaissance love. Eros, passion, and friendship in Italian art around 1500 , Berlin 2014.

\section{Kurz 1953}

O. Kurz, 'Huius nympha loci. A pseudo-classical inscription and a drawing by Dürer', Journal of the Warburg and Courtauld Institutes 16 (1953), 171-177.

\section{Lehman 2007-2008}

A-S. Lehman, "Fleshing out the body. The "colours of the naked" in workshop practice and art theory, 1400-1600', Netherlands Yearbook for the History of Art / Nederlands Kunsthistorisch Jaarboek 58 (2007-2008), 87-109.

\section{Liebmann 1968}

M. Liebmann, 'On the iconography of the Nymph of the Fountain by Lucas Cranach the Elder', Journal of the Warburg and Courtauld Institutes 31 (1968), 434-437.

\section{Lipińska 2013}

A. Lipinska, 'Alabastrum, id est, corpus hominis. Alabaster in the Low Countries, a cultural history', Netherlands Yearbook for the History of Art /Nederlands Kunsthistorisch Jaarboek 62 (2013), 85-115.

\section{Lipinska 2015}

A. Lipińska, Moving sculptures. Southern Netherlandish alabasters from the 16 th to 17 th centuries in central and northern Europe, Leiden 2015 , $81-89$

Lucretius 1992

Lucretius, De rerum natura (W.H.D. Rouse, trans.; M.F. Smith, rev.), Cambridge, MA 1992. 
MacDougall 1975

E.B. MacDougall, 'The sleeping nymph. Origins of a humanist fountain type', Art Bulletin 57 (1975), 357-365.

\section{McGowan 2015}

M.M. McGowan, Ronsard and the visual arts. A study of poetic creativity',Journal of the Warburg and Courtauld Institutes 78 (2015), 173-205.

\section{Melion 1991}

W.S. Melion, Shaping the Netherlandish canon. Karel van Mander's 'Schilder-Boeck', Chicago 1991.

\section{Melion 2001}

W. Melion, 'Vivae dixisses virginis ora. The discourse of color in Hendrick Goltzius's Pygmalion and the ivory statue', Word and Image 17 (2001), 153-176

\section{Muller 1982}

J. Muller, 'Rubens's theory and practice of the imitation of art', Art Bulletin 64 (1982), 229-247.

\section{Cat. New York 2010}

Cat. New York, Metropolitan Museum of Art, Man, myth, and sensual pleasures. Jan Gossart's Renaissance (M.W. Ainsworth, ed.), New York 2010.

\section{Ovid 1984}

Ovid, Metamorphoses (F.J. Miller, trans; G.P. Goold, rev.), Cambridge, MA 1984 .

\section{Paton 1918}

W.R. Paton (trans.), The Greek anthology, Cambridge, MA 1918.

\section{Pigman 1980}

G.W. Pigman, 'Versions of imitation in the Renaissance', Renaissance Quarterly 33 (1980), 1-32.

\section{Pollitt $199^{\circ}$}

J.J. Pollitt, The art of ancient Greece. Sources and documents, Cambridge 1990.

\section{Prandoni 2014}

M. Prandoni, Vive la France, À bas la France! Contradictory attitude toward the appropriation of French cultural elements in the second half of the sixteenth century. The forewords of "modern" poetry collections', in: Wissenstransfer und Auctoritas in der frühneuzeitlichen niederländischsprachigen Literatur (B. Noak, ed.), Göttingen 2014, 179-194.

\section{Price 1992}

D. Price, 'The poetics of license in Janus Secundus's Basia', Sixteenth Century Journal 23 (1992), 289-301.

\section{Price 1996}

D. Price, Janus secundus, Tempe 1996.

\section{Ramakers 2009}

B. Ramakers, 'Art and artistry in Lucas de Heere', Netherlands Yearbook for the History of Art / Nederlands Kunsthistorisch Jaarboek 59 (2009), 164-192.

\section{Ramakers 2012}

B. Ramakers, 'As many lands, as many customs. Vernacular selfawareness among the Netherlandish rhetoricians', in: Keizer \& Richardson 2012, 123-177.

\section{Ronsard 1974}

P. de Ronsard, Les amours (F. Joukovsky, ed.), Paris 1974.

\section{Ronsard 2002}

P. de Ronsard, Selected poems (M. Quainton \& E. Vinestock, trans.), London 2002

\section{Rosand 1981}

D. Rosand, 'Titian and the eloquence of the brush', Artibus et Historiae $2(1981), 85-96$.

\section{Simons 2009}

P. Simons, 'Manliness and the visual semiotics of bodily fluids in early modern culture',Joumal of Medieval and Earby Modern Studies 39 (2009), 331-373

\section{Smith 2004}

J.C. Smith, The northern Renaissance, London \& New York 2004.

\section{Stoichita 2008}

V. Stoichita, The Pygmalion effect. From Orid to Hitchcock, Chicago 2008.

\section{Trevisani \& Gasparotto 2009}

F. Trevisani \& D. Gasparotto (eds.), Bonacolsi l'antico. Una scultore nella Mantova di Andrea Mantegna e di Isabella d'Este, Milan 2009.

\section{Turner 2008}

J.G. Turner, 'Profane love. The challenge to sexuality', in: cat. New York, Metropolitan Museum of Art, Art and love in Renaissance Italy (A. Bayer, ed.), New York 2008, 178-184.

\section{Urbach 1995}

S. Urbach, "Sacra nos monet, docetque historia". An unknown Susanna and the elders by Willem Key', in: Shop talk. Studies in honor of Seymour Stive, presented on his seventy-fifth birthday (C.P. Schneider et al, eds), Cambridge 1995, 249-253.

Waite zooo

G.K. Waite, Reformers on stage. Popular drama and religious propaganda in the low countries of Charles V, 1515-1556, Toronto 2000.

\section{Weber 1997}

H. Weber, 'La célébration du corps féminin dans Les amours de Ronsard. Variations sur un répertoire connu', Bulletin de l'Association d'étude sur l'humanisme, la réforme et la renaissance 45 (1997), 7-23.

\section{Weissert 201}

C. Weissert, "The annexation of the antique. The topic of the living picture in sixteenth-century Antwerp', in: Understanding art in Antwerp. Classicising the popular, popularising the classic $(1540-1580)$ (B. Ramakers, ed.), Leuven 2011, 53-67.

\section{Woods 2007}

K. Woods, Imported images. Netherlandish Late Gothic sculpture in England, c. 1400-C. 1550, Donington 2007. 